\title{
The Concept of 'Place of Safety': Yet Another Self- Contained Maritime Rule or a Sustainable Solution to the Ever-Controversial Question of Where to Disembark Migrants Rescued at Sea?
}

\author{
Martin Ratcovich*
}

\section{Introduction}

The adoption of amendments to the International Convention on Maritime Search and Rescue, ${ }^{1}$ and the International Convention for the Safety of Life at Sea, ${ }^{2}$ was a consequence of the well-known Tampa affair. ${ }^{3}$ The amendments introduced the

* LLM (Lund), Doctoral Candidate, Faculty of Law, Stockholm University. Martin Ratcovich was a visiting researcher at the ANU College of Law, Australian National University in March-April 2014. He has previously worked at the Ministry of Defence of Sweden and at the Swedish Coast Guard Headquarters. He has also served as Legal Assistant to the Nordic member of the United Nations International Law Commission, ambassador Marie Jacobsson (LLD). The author would like to thank Professor Said Mahmoudi, Stockholm University, for helpful comments. The author would also like to thank Professor Donald R Rothwell, Associate Professor David Letts and Senior Lecturer Sarah Heathcote, ANU College of Law. Any errors or omissions remain the author's own.

1 International Convention on Maritime Search and Rescue, opened for signature 1 November 1979, 1405 UNTS 109 (entered into force 22 June 1985) ('SAR Convention').

2 International Convention for the Safety of Life at Sea, opened for signature 1 November 1974, 1184 UNTS 278 (entered into force 25 May 1980) ('SOLAS Convention').

$3 \quad M / V$ Tampa ('Tampa') was a Norwegian container ship that on 26 August 2001 was asked by the Australian Rescue Coordination Centre to assist in the search and rescue operation for an Indonesian ship in the waters between Indonesia and Christmas Island (Australia). The Tampa found the Indonesian ship in a sinking condition approximately 75 nautical miles off Christmas Island. After having rescued and taken on board some 430 persons most of whom were asylum-seekers from Afghanistan - the Tampa resumed its northbound voyage with the plan to disembark the rescued persons along the way in Indonesia about 250 nautical miles to the north. However, the course was changed and set for Christmas Island in response to pressure from some of the rescued persons. This led Australian authorities to inform the master of the Tampa that the Australian territorial sea was closed to the ship and that the course should be changed for Indonesia and that failure to do so would lead to prosecution for people smuggling. After waiting a couple of days offshore Christmas Island and the health condition of some of the rescued persons began to deteriorate, the Tampa issued a distress signal and headed towards Christmas Island. Within short, the Tampa was boarded by Australian special military forces. The rescued asylum-seekers were eventually transferred to an Australian warship that would take them to Papua New Guinea, from where they would be transported to Nauru and New Zealand 
concept of 'place of safety' in the legal framework governing maritime search and rescue - the basic intent of which is that everyone rescued at sea shall be disembarked and delivered to 'a place of safety'. ${ }^{4}$ However, what is meant by 'place of safety' is defined in neither the SOLAS Convention nor the SAR Convention nor any other treaty. Instead, the application of the concept is guided by a set of guidelines developed by the International Maritime Organization ('IMO'): Guidelines on the Treatment of Persons Rescued at Sea. ${ }^{5}$ However, many aspects are left undecided and the interpretation is varying in practice.

Another notable consequence of the Tampa affair was the introduction of a hardened asylum-seeker policy in Australia, commonly known as the Pacific Solution. ${ }^{6}$ The legislative changes, which put in place an array of measures aimed at deterring asylum-seekers from irregularly entering Australia, were complemented by a new maritime border campaign to further deter asylum-seekers from trying to reach Australia by boat. The campaign was led by the Australian Defence Force and became codenamed Operation Relex. ${ }^{7}$ The operation was aimed at preventing and deterring socalled 'Suspected Illegal Entry Vessels' from entering Australian waters, but was also used to keep away vessels by turning them around, including by forcible towage. Following strong critique, both domestically and internationally, the Pacific Strategy was eventually abolished in 2008. However, in response to increasing numbers of unauthorised maritime arrivals, some central components of the Pacific Strategy were reintroduced in Australia in 2013. The perhaps most notable recurrence was so-called offshore processing - a mechanism under which undocumented migrants are taken to processing centres located in other countries than Australia. ${ }^{8}$ Similar to what followed

for further processing. For further descriptions of the Tampa affair, see D R Rothwell, 'The Law of the Sea and the MV Tampa Incident: Reconciling Maritime Principles with Coastal State Sovereignity' (2002) 13 Public Law Review 118; Mary Crock and Laurie Berg, Immigration, Refugees and Forced Migration: Law, Policy and Practice in Australia (Federation Press, 2011) 89-97 [4.31]-[4.48]; R Barnes, 'Refugee Law at Sea' (2004) 53 International and Comparative Law Quarterly 47, 48.

4 The concept of place of safety is found in the SOLAS and SAR Conventions. See below Part II(b).

5 Guidelines on the Treatment of Persons Rescued at Sea, Maritime Safety Committee ('MSC') Res.167(78), 78 ${ }^{\text {th }}$ sess, Agenda Item 26, IMO Doc MSC 78/26/Add.2 annex 34 (4 June 2004, adopted 20 May 2004) ('IMO Guidelines').

6 The policy package introduced in Australia after the Tampa affair was first known as the Pacific Solution but was later changed to the Pacific Strategy, seemingly because of the first name's 'unfortunate (genocidal) connotations': Crock and Berg, above n 3, 81 n 24.

7 Operation Relex was instigated in September 2001 and ended in March 2002, when it was replaced by Operation Relex II which lasted until mid-July 2006.

8 As of January 2015, about 1800 persons were held at processing centres in Nauru and Papua New Guinea. About 2000 persons were held in immigration detention centres, including around 300 in detention facilities on Christmas Island: Australian Government Department of Immigration and Border Protection, Immigration Detention and Community Statistics $\quad 31 \quad$ Summary: $\quad 3015$ 
after the Tampa affair, the legislative changes were complemented by a new maritime border campaign to 'stop the boats': Operation Sovereign Borders. ${ }^{9}$

The aim of this article is to examine the concept of place of safety, as found in the SOLAS and SAR Conventions. The principal argument put forward is that the concept needs to be interpreted in the wider context of international law, including through systemic integration, so that other relevant and applicable rules of international law are taken into account. ${ }^{10}$ It is argued that a restrictive ('non-systemic') interpretation, whereby the international law of the sea is perceived as a self-contained regime, risks exposing refugees and asylum-seekers rescued at sea to less favourable treatment than they are entitled to under existing international law. The analysis is illustrated by references to Australian legislation, jurisprudence and practice related to Operation Sovereign Borders.

The first part of this article provides an overview of the relevant legal framework: the duty to render assistance at sea, the concept of place of safety and the basic rules on interpretation of treaties. The second part contains an outline of systemic interpretation of the concept of place of safety, including a systematisation of the basic rules for rescue of refugees and asylum-seekers at sea. The third and last part provides an illustration with reference to Australia. The article ends with some brief concluding remarks.

\section{PART I - LEGAL FRAMEWORK}

\section{(a) The duty to render assistance at sea}

The delivery of assistance to those in peril at sea is a central principle of life at sea. It is also an ancient obligation of international law and 'one of the traditional hallmarks of the law of the sea'. ${ }^{11}$ Important expressions of that principle in treaty law include the SOLAS and SAR Conventions, the International Convention on Salvage and the United

<https://www.border.gov.au/ReportsandPublications/Documents/statistics/immigrationdetention-statistics-jan2015.pdf>.

9 Operation Sovereign Borders was introduced shortly after the Coalition, led by Tony Abbot, had won the 2013 Federal Election in Australia. An election commitment of the Coalition was to 'stop the boats' by instructing the Australian Defence Force to 'turn back boats where it is safe to do so'. See, eg, Liberal Party of Australia and the Nationals for Regional Australia, 'The Coalition's Operation Sovereign Borders Policy' (Policy Document, July 2013) <http://www.liberal.org.au/our-policies>. See below Part III.

10 Following Vienna Convention on the Law of Treaties, opened for signature 23 May 1969, 1155 UNTS 331 (entered into force 27 January 1980) art 31(3)(c) ('VCLT'): 'There shall be taken into account, together with the context ... any relevant rules of international law applicable in the relations between the parties'.

11 B H Oxman, 'Human Rights and the United Nations Convention on the Law of the Sea' (1998) 36 Columbia Journal of Transnational Law 399, 414. 'The duty to render assistance to any person found in danger at sea has been accepted from time immemorial': Djamchid Momtaz, 'The High Seas' in René-Jean Dupuy and Daniel Vignes, A Handbook on the New Law of the Sea (Martinus Nijhoff, 1991) vol 1, 383, 416. 
Nations Convention on the Law of the Sea. ${ }^{12}$ The wording used in each treaty is similar and the instruments provide a fairly coherent, yet multifaceted, picture of the duty - at least as concerns flag state obligations. While the SOLAS Convention requires ' $\mathrm{t}] \mathrm{he}$ master of a ship at sea which is in a position to be able to provide assistance, on receiving information from any source that persons are in distress at sea ... to proceed with all speed to their assistance', the SAR Convention requires its parties to ensure 'that assistance be provided to persons in distress at sea'. ${ }^{13}$ The Salvage Convention provides that '[e]very master is bound, so far as he can do so without serious danger to his vessel and persons thereon, to render assistance to any person in danger of being lost at sea' and that its 'States Parties shall adopt the measures necessary to enforce [this] duty'. ${ }^{14}$ The arguably most important expression of the duty to render assistance at sea is found in art 98(1) of the UNCLOS. It reads:

Every State shall require the master of a ship flying its flag, in so far as he can do so without serious danger to the ship, the crew or the passengers:

(a) to render assistance to any person found at sea in danger of being lost;

(b) to proceed with all possible speed to the rescue of persons in distress, if informed of their need of assistance, in so far as such action may reasonably be expected of him;

(c) after a collision, to render assistance to the other ship, its crew and its passengers and, where possible, to inform the other ship of the name of his own ship, its port of registry and the nearest port at which it will call.

Although this provision is found in pt VII of the UNCLOS, which deals with the high seas, it is generally accepted that the duty to render assistance at sea applies irrespective of maritime zone. As for the exclusive economic zone, the situation is relatively clear since art 58(2) of the UNCLOS states that the provisions concerning the high seas also apply to the exclusive economic zone, in so far as they are not incompatible with the convention's rules on the exclusive economic zone. Since there is no reason to believe that the duty to render assistance at sea would be incompatible with any of the convention's rules on the exclusive economic zone - which mainly concern the allocation of rights and duties in the exclusive economic zone and the utilisation of living resources ${ }^{15}$ - it is reasonable to assume that art 98(1) of the $U N C L O S$ also applies to the exclusive economic zone.

What is more thought-provoking is that the UNCLOS does not include any similar provision on the applicability to the territorial sea. Hence, it may be asked if there is a

12 SOLAS Convention annex ch $\mathrm{V}$ reg 33; SAR Convention annex paras 2.1.1, 2.1.10; International Convention on Salvage, opened for signature 1 July 1989, 1953 UNTS 165 (entered into force 14 July 1996) arts 10(1)-(2) ('Salvage Convention'); United Nations Convention on the Law of the Sea, opened for signature 10 December 1982, 1833 UNTS 3 (entered into force 16 November 1994) art 98 ('UNCLOS').

13 SOLAS Convention annex ch V reg 33(1); SAR Convention annex para 2.1.10.

14 Salvage Convention arts 10(1)-(2).

15 See, eg, UNCLOS arts 56, 58, 61-8. 
duty to render assistance to persons in distress at sea in the territorial sea. Arguably, the better answer is yes. Such an obligation exists under both treaty law and customary international law. Although art 98(1) of the UNCLOS does not refer explicitly to the territorial sea it should be interpreted to include the territorial sea. ${ }^{16}$

It follows already from the text that the duty is not limited to any particular maritime zone, since there is no reference to any maritime zone whatsoever. Instead, the terms 'any person found at sea in danger of being lost' indicate a broad interpretation, geographically limited only by the terms 'at sea'. ${ }^{17}$ It is essentially only the location of art 98(1) in pt VII of the UNCLOS that indicates a geographically limited applicability. However, another contextual element indicates that the duty to render assistance applies to the territorial sea. ${ }^{18}$ This provision concerns innocent passage of the territorial sea and provides that 'innocent passage includes stopping and anchoring, but only in so far as the same are ... rendered necessary ... for the purpose of rendering assistance'.$^{19}$ The context of art 98(1) can thus be drawn on to support arguments both for and against a limited geographical scope.

However, the object and purpose indicates a broad geographical scope, irrespective of maritime zone. In the absence of subsequent agreements or subsequent practice within the meaning of arts 31(3)(a)-(b) of the VCLT, the element referred to as 'any [other] relevant rules of international law applicable in the relations between the parties' is of significant importance to the interpretation. ${ }^{20}$ An important source in this regard is the customary duty to render assistance to persons in distress at sea. ${ }^{21}$ In examining the geographical scope of the customary duty to render assistance at sea it needs to be noted that both the SOLAS Convention and the SAR Convention impose obligations to render assistance within the territorial sea. ${ }^{22}$ Similarly, the Salvage

16 Following the general rule of interpretation, as found in VCLT art 31: 'A treaty shall be interpreted in good faith in accordance with the ordinary meaning to be given to the terms of the treaty in their context and in the light of its object and purpose'. See below Part II(c). 17 UNCLOS art 98(1) (emphasis added).

18 Ibid art 18.

19 Ibid art 18(2) (emphasis added). Seemingly presupposing a duty to render assistance in the territorial sea.

20 VCLT art 31(3)(c).

21 The existence of a customary duty to render assistance to persons in distress at sea is indicated by the fact that a near-identical provision was included in Convention on the High Seas, opened for signature 29 April 1958, 450 UNTS 11 (entered into force 30 September 1962) art 12. Additionally, the United Nations International Law Commission ('ILC'), when drafting the provision, intended it to state the existing international law: International Law Commission, 'Report of the International Law Commission Covering the Work of its Eighth Session’ [1956] 2 Yearbook of the International Law Commission 253.

22 SOLAS Convention annex ch V reg 1(1) provides, '[u]nless expressly provided otherwise, this chapter shall apply to all ships on all voyages except [government ships]; and ships solely navigating the Great Lakes of North America'. SAR Convention annex para 2.1 does not refer to any geographical limitation when it provides, '[o]n receiving information that 
Convention presupposes the existence of such a duty within the territorial sea. ${ }^{23}$ As result, it is reasonable to believe that the customary duty to render assistance at sea applies to the territorial sea. This also explains why art 18 of the UNCLOS assumes the existence of a duty to render assistance in the territorial sea despite the absence of an explicit provision to this end. This interpretation is also supported by legal literature. ${ }^{24}$

A fundamental aspect of the duty to render assistance at sea is its non-discriminatory nature. While art 98(1) of the UNCLOS refers to 'any person', the relevant provisions of the SOLAS and SAR Conventions contain explicit prohibitions of discrimination ('regardless of the nationality or status of such a person or the circumstances in which that person is found'). ${ }^{25}$ A perhaps even more illustrative wording is found in the International Convention for the Unification of Certain Rules of Law Relating to Assistance and Salvage at Sea, which provides that assistance shall be rendered 'to everybody, though an enemy, found at sea in danger of being lost'. 26

\section{(ii) Coastal state obligations}

The duty to render assistance to persons in distress at sea involves obligations also for coastal states. These obligations concern operation and provision of maritime search and rescue services. Article 98(2) of the UNCLOS reads:

any person is, or appears to be, in distress at sea, the responsible authorities of a Party shall take urgent steps to ensure that the necessary assistance is provided'.

23 Salvage Convention art 10 provides, without any geographical limitation: 'Every master is bound, so far as he can do so without serious danger to his vessel and persons thereon, to render assistance to any person in danger of being lost at sea'.

24 See, eg, Oxman, above n 11, 415: '[UNCLOS art 18] is not properly regarded as articulating a new right or the expansion of an existing right ... [but] constitutes a recognition that a universal duty to rescue at sea has existed since time immemorial, that this duty has been respected without regard to changing views regarding the juridical status of the sea, and that this duty finds new support in modern international law in the increasing acceptance of humanitarian norms in state practice and conventional law'. In the authoritative commentary on the UNCLOS it is stated that 'the duty to render assistance exists throughout the ocean, whether in the territorial sea, in straits used for international navigation, in archipelagic waters, in the exclusive economic zone or on the high seas': Satya Nandan and Shabtai Rosenne (eds), United Nations Convention on the Law of the Sea 1982 (Brill, 1995) vol 3, 177. See also Roland Bank, 'Article 11: Refugee Seamen' in Andreas Zimmerman, Jonas Dörschner and Felix Machts (eds), The 1951 Convention Relating to the Status of Refugees and its 1967 Protocol: A Commentary (Oxford University Press, 2011) 853; A Proelss, 'Rescue at Sea Revisited: What Obligations Exist Towards Refugees?’ [2008] Scandinavian Institute of Maritime Law Yearbook 1.

25 SOLAS Convention annex ch V reg 33(1); SAR Convention annex para 2.1.10.

26 International Convention for the Unification of Certain Rules of Law Relating to Assistance and Salvage at Sea, opened for signature 23 September 1910, UKTS 4 (1913) Cd 6677 (entered into force 1 March 1913) art 11. 
Every coastal State shall promote the establishment, operation and maintenance of an adequate and effective search and rescue service regarding safety on and over the sea and, where circumstances so require, by way of mutual regional arrangements cooperate with neighbouring States for this purpose.

In the same way as its preceding paragraph, art 98(2) applies to the exclusive economic zone, although it is found in pt VII of the UNCLOS. ${ }^{27}$

The more detailed legal framework for coastal states' obligations concerning maritime search and rescue is found in the SOLAS and SAR Conventions. The basic obligation to establish a maritime search and rescue service is set out in the SOLAS Convention:

Each Contracting Government undertakes to ensure that necessary arrangements are made for ... rescue of persons in distress at sea around its coasts. These arrangements shall include the establishment, operation and maintenance of such search and rescue facilities as are deemed practicable and necessary, having regard to the density of the seagoing traffic and the navigational dangers, and shall, so far as possible, provide adequate means of locating and rescuing such persons. ${ }^{28}$

The more specific rules are found in the SAR Convention, the basic obligation of which reads:

Parties shall ... participate in the development of search and rescue services to ensure that assistance is rendered to any person in distress at sea. On receiving information that any person is, or appears to be, in distress at sea ... a Party shall take urgent steps to ensure that the necessary assistance is provided.

Parties shall ... establish the following basic elements of a search and rescue service:

1 legal framework;

2 assignment of a responsible authority;

3 organisation of available resources;

4 communication facilities;

5 co-ordination and operational functions; and

6 processes to improve the service including planning, domestic and international cooperative relationships and training. ${ }^{29}$

The SAR Convention provides a comprehensive and detailed framework for the establishment, maintenance and provision of maritime search and rescue services. Central features are the obligation of parties to establish search and rescue regions, ${ }^{30}$

\section{Cf UNCLOS art 58(2). \\ SOLAS Convention annex ch $\mathrm{V}$ reg $7(1)$. \\ SAR Convention annex paras 2.1.1-2.1.2.}

Search and rescue regions should be contiguous and, as far as practical, not overlap. They shall be established by agreement, which shall be recorded by the parties or set out in written plans by the parties. The delimitation of search and rescue regions is not related to and shall not prejudice the delimitation of any boundary between States: ibid annex paras 2.1.4, 2.1.6-2.1.7. 
and to use search and rescue units and other available facilities for providing assistance to a person who is, or appears to be, in distress at sea within such regions. ${ }^{31}$ To meet their obligations, parties shall establish rescue co-ordination centres for their search and rescue services and such rescue sub-centres as they consider appropriate. ${ }^{32}$ Rescue coordination centres shall be operational on a 24-hour basis and be constantly staffed by trained personnel. ${ }^{33}$

The legal framework for maritime search and rescue services is supported by the International Aeronautical and Maritime Search and Rescue Manual, ${ }^{34}$ which provides non-binding guidelines for a common aviation and maritime approach to organising and providing search and rescue services. The SOLAS Convention requires all ships to carry an up-to-date copy of parts of the IAMSAR Manual. ${ }^{35}$ The IAMSAR Manual includes numerous references to the concept of place of safety. ${ }^{36}$

\section{(b) The concept of place of safety}

As a result of the Tampa affair, the Assembly of the IMO ordered a review of the existing treaty law for the purpose of identifying any existing gaps, inconsistencies, ambiguities, vagueness or other inadequacies associated with the treatment of persons rescued at sea. ${ }^{37}$ Given its multi-disciplinary nature, the issue was brought to the attention of a number of other specialised agencies and programmes of the United Nations pointing out the need for a co-ordinated approach. An inter-agency group was set up in 2002 comprising, among others, the IMO, the United Nations Division for Ocean Affairs and the Law of the Sea, the United Nations High Commissioner for Refugees ('UNHCR'), the United Nations Office on Drugs and Crime, the Office of the

Ibid annex para 2.1.9.

Ibid annex para 2.3.1.

Ibid annex para 2.3.3.

International Civil Aviation Organization and the International Maritime Organization, International Aeronautical and Maritime Search and Rescue Manual (IMO Publishing, $9^{\text {th }}$ ed, 2013) vols 1-3 ('IAMSAR Manual').

35 SOLAS Convention annex ch V reg 21(2).

36 See, eg, IAMSAR Manual vol I (Organization and Management) paras 1.4.1, 2.5.1, 6.1.1, 6.3.3, app L; IAMSAR Manual vol 2 (Mission Co-Ordination) paras 1.6.11, 4.2.1(a), 6.15.29, 6.15.27, app C, app G; IAMSAR Manual vol 3 (Mobile Facilities) 2-38.

37 The objectives were to help ensure that '(1) survivors of distress incidents are provided assistance regardless of nationality or status or the circumstances in which they are found; (2) ships, which have retrieved persons in distress at sea, are able to deliver the survivors to a place of safety; and (3) survivors, regardless of nationality or status, including undocumented migrants, asylum seekers and refugees, and stowaways, are treated, while on board, in the manner prescribed in the relevant IMO instruments and in accordance with relevant international agreements and long-standing humanitarian maritime traditions': Review of Safety Measures and Procedures for the Treatment of Persons Rescued at Sea, IMO A Res 920(22), 22 ${ }^{\text {nd }}$ sess, Agenda Item 8, A22/Res.920 (22 January 2002, adopted 29 Nobember 2001) [1]. See also IMO Guidelines, IMO Doc MSC 78/26/Add.2 annex 34, annex para 2.1 . 
United Nations High Commissioner for Human Rights, and the International Organization for Migration. ${ }^{38}$ Several inter-agency meetings were held in the following years. The conclusions of the meetings formed the basis for legislative amendments that introduced the concept of place of safety into the disembarkation rules: the 2004 amendments to the SOLAS and SAR Conventions. ${ }^{39}$

\section{(i) SAR Convention}

The SAR Convention comprises a preamble, eight articles and an annex, which is an integral part of the convention. ${ }^{40}$ The parties to the SAR Convention undertake to adopt all legislative or other appropriate measures necessary to give full effect to the convention and its annex. ${ }^{41}$ Following the 2004 amendments, ${ }^{42}$ the phrase 'place of safety' is found in two rules of the annex:

The terms listed below are used in the Annex with the following meanings:

2 'Rescue'. An operation to retrieve persons in distress, provide for their initial medical or other needs, and deliver them to a place of safety; 43

Parties shall co-ordinate and co-operate to ensure that masters of ships providing assistance by embarking persons in distress at sea are released from their obligations with minimum further deviation from the ships' intended voyage, provided that releasing the master of the ship from these obligations does not further endanger the safety of life at sea. The Party responsible for the search and rescue region in which such assistance is rendered shall exercise primary responsibility for ensuring such co-ordination and cooperation occurs, so that survivors assisted are disembarked from the assisting ship and delivered to a place of safety, taking into account the particular circumstances of the case and guidelines developed by the Organization. In these cases, the relevant Parties shall arrange for such disembarkation to be effected as soon as reasonably practicable. ${ }^{44}$

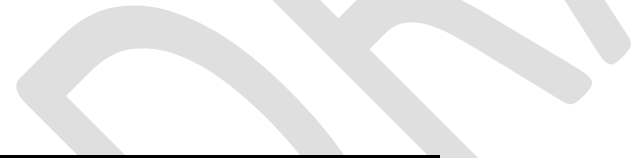

38 See, eg, Draft Progress Report to the Assembly Pursuant to Operative Paragraph 5 of Resolution A.920(22) on Review of Safety Measures and Procedures for the Treatment of Persons Rescued at Sea, MSC, $77^{\text {th }}$ sess, Agenda Item 10, IMO Doc MSC 77/10/3 (17 February 2003) <https://docs.imo.org>.

39 For a detailed description of the legislative background, see generally Jasmine Coppens and Eduard Somers, 'Towards New Rules on Disembarkation of Persons Rescued at Sea?' (2010) 25 International Journal of Marine and Coastal Law 377, 384.

40 SAR Convention art I provides: 'Unless expressly provided otherwise, a reference to the Convention constitutes at the same time a reference to its Annex'.

41 Ibid art I.

42 See Adoption of Amendments to the International Convention on Maritime Search and Rescue, 1979, as Amended, MSC Res.155(78), $78^{\text {th }}$ sess, Agenda Item 26, IMO Doc MSC 78/26/Add.1 annex 5 (4 June 2004, adopted 20 May 2004) ('2004 Amendments to the SAR Convention').

43 SAR Convention annex para 1.3.2 (emphasis added).

44 Ibid annex para 3.1.9 (emphasis added). 
The 2004 amendments also entailed other changes, including inter alia the notion of a person in distress at sea, ${ }^{45}$ and the authority and responsibility of rescue coordination centres to identify place(s) for disembarking persons found in distress at sea. ${ }^{46}$ The amendments were adopted in response to 'the need for clarification ... to guarantee that persons rescued at sea will be provided a place of safety regardless of their nationality, status or the circumstances in which they are found'. ${ }^{47}$ The preamble to the amendments importantly sets out that 'the intent ... is to ensure that in every case a place of safety is provided within a reasonable time [and] that the responsibility to provide a place of safety, or to ensure that a place of safety is provided, falls on the Party responsible for the SAR region in which the survivors were recovered'. 48

The 2004 amendments were adopted after considerations within the IMO pursuant to a procedure provided for in the SAR Convention. ${ }^{49}$ According to this procedure, the amendments were deemed to have been accepted one year after the date on which they were communicated to the parties for acceptance. The amendments entered into force six months later with respect to all parties, except for Malta which had objected to them. ${ }^{50}$

\section{(ii) SOLAS Convention}

The 2004 Amendments to the SAR Convention were adopted together with amendments to the SOLAS Convention. ${ }^{51}$ The SOLAS Convention is the principal instrument on maritime safety and provides detailed rules on the construction, equipment and operation of ships. The SOLAS Convention has been revised and amended numerous times. Similar to the SAR Convention, the material obligations are found in an annex, which is an integral part of the convention. ${ }^{52}$ The parties undertake to give effect to the provisions of the SOLAS Convention and its annex. ${ }^{53}$ Consistently with the

45 Ibid para 2.1.1.

$46 \quad$ Ibid paras 3.1.4, 4.8.5

$47 \quad$ Ibid Preamble para 7.

48 Ibid Preamble para 8.

49 Cf SAR Convention art III(2)(f).

50 Cf ibid art III(2)(h), which states that amendments in accordance with the procedure in art III(2)(f) 'shall enter into force: with respect to all Parties, except those which have objected to the amendment ... and which have not withdrawn such objections, six months after the date on which it is deemed to have been accepted' the procedure for entry into force of amendments by the procedure specified in art III (2)(f). For the status of the SAR Convention, see International Maritime Organization, Status of Multilateral Conventions (26 February 2016) <http://www.imo.org/en/About/Conventions/StatusOfConventions/>.

51 Adoption of Amendments to the International Convention on Safety of Lives at Sea, 1974, as amended, MSC Res.153(78), $78^{\text {th }}$ sess, Agenda Item 26, IMO Doc MSC 78/26/Add.1 annex 3 (4 June 2004, adopted 20 May 2004) ('2004 Amendments to the SOLAS Convention').

52 SOLAS Convention art I(a) provides: 'Every reference to the present Convention constitutes at the same time a reference to the annex'.

53 Ibid. 
corresponding provision in the SAR Convention and following the 2004 amendments, the SOLAS Convention provides:

Contracting Governments shall co-ordinate and co-operate to ensure that masters of ships providing assistance by embarking persons in distress at sea are released from their obligations with minimum further deviation from the ships' intended voyage, provided that releasing the master of the ship from the obligations under the current regulation does not further endanger the safety of life at sea. The Contracting Government responsible for the search and rescue region in which such assistance is rendered shall exercise primary responsibility for ensuring such co-ordination and co-operation occurs, so that survivors assisted are disembarked from the assisting ship and delivered to a place of safety, taking into account the particular circumstances of the case and guidelines developed by the Organization. In these cases the relevant Contracting Governments shall arrange for such disembarkation to be effected as soon as reasonably practicable. ${ }^{54}$

Similar to the 2004 Amendments to the SAR Convention, the preamble to the 2004 Amendments to the SOLAS Convention sets out 'that the intent ... is to ensure that in every case a place of safety is provided within a reasonable time [and that] ... the responsibility to provide a place of safety, or to ensure that a place of safety is provided, falls on the Contracting Government responsible for the search and rescue region in which the survivors were recovered'.55 As with the amendments to the $S A R$ Convention, Malta objected to the 2004 Amendments to the SOLAS Convention. ${ }^{56}$

(iii) IMO Guidelines on the Treatment of Persons Rescued at Sea

The 2004 amendments to the SOLAS and SAR Conventions were adopted together with a set of guidelines provided for in the amendments: the IMO Guidelines on the Treatment of Persons Rescued at Sea. ${ }^{57}$ Although the guidelines do not establish any

54 SOLAS Convention annex ch $\mathrm{V}$ reg 33(1-1) (emphasis added).

552004 Amendments to the SOLAS Convention, IMO Doc MSC 78/26/Add.1 annex 3, Preamble para 8.

56 Somewhat curiously, Finland also objected to the amendments to the SOLAS Convention and has as of March 2015 not withdrawn its objection. Finland also objected to the 2004 Amendments to the SAR Convention, IMO Doc MSC 78/26/Add.1 annex 5, but has thereafter withdrawn this objection: International Maritime Organization, above $\mathrm{n} 50$.

57 IMO Guidelines, IMO Doc MSC 78/26/Add.2 annex 34, annex para 1.1 provides that '[t]he purpose of these Guidelines are to provide guidance to Governments and to shipmasters with regard to humanitarian obligations and obligations under the relevant international law relating to treatment of persons rescued at sea'. Furthermore, para 2.2 provides that ' $[t]$ hese Guidelines are intended to help Governments and masters better understand their obligations under international law and provide helpful guidance with regard to carrying out these obligations'. The guidelines should not be confused with IMO, UNHCR and the International Chamber of Shipping, 'Rescue at Sea: a Guide to Principles and Practices as Applied to Refugees and Migrants' (Leaflet, September 2006). It provides guidance on relevant legal provisions and on practical procedures to ensure the prompt disembarkation of survivors of rescue operations, and measures to meet their specific needs, particularly in the case of refugees and asylum-seekers. It is of non-binding character and is intended for shipmasters, shipowners, government authorities, insurance companies, and other interested 
new binding legal obligations they provide important means for interpreting the obligations to render assistance at sea and the treatment of rescued persons. ${ }^{58}$

The guidelines provide guidance for shipmasters, governments and rescue coordination centres, and comments on relevant international law. Rescue coordination centres are urged to have effective plans of operation and arrangements in place for responding to all types of SAR situations, covering how the centre could co-ordinate:

a recovery operation; disembarkation of survivors from a ship; delivery of survivors to a place of safety; and its efforts with other entities (such as customs and immigration authorities, or the ship owner or flag State), should non-SAR issues arise while survivors are still aboard the assisting ship with regard to nationalities, status or circumstances of the survivors; and quickly address initial border control or immigration issues to minimize delays that might negatively impact the assisting ship, including temporary provisions for hosting survivors while such issues are being resolved. 59

The most important feature of the guidelines is probably their contribution to the understanding of the concept of 'place of safety'. The texts of the SOLAS and SAR Conventions do not specify what is meant by 'place of safety'. The only guidance given is that the interpretation should take into account 'the particular circumstances of the case and [the IMO Guidelines]'. ${ }^{60}$ The guidelines repeatedly point to the responsibility of the government in whose search and rescue region assistance is provided for arranging a place of safety. ${ }^{61}$ As to the meaning of 'place of safety', paras 6.12-6.15 provide:

A place of safety ... is a location where rescue operations are considered to terminate. It is also a place where the survivors' safety of life is no longer threatened and where their basic human needs (such as food, shelter and medical needs) can be met. Further, it is a place from which transportation arrangements can be made for the survivors' next or final destination.

An assisting ship should not be considered a place of safety based solely on the fact that the survivors are no longer in immediate danger once aboard the ship. An assisting ship may not have appropriate facilities and equipment to sustain additional persons on board without endangering its own safety or to properly care for the survivors. Even if the ship

parties involved in rescue at sea situations. As opposed to the IMO Guidelines, the UNHCR/IMO leaflet has no legal value.

58 This understanding is supported by Richard Barnes, 'The International Law of the Sea and Migration Control' in Bernard Ryan and Valsamis Mitsilegas (eds), Extraterritorial Immigration Control: Legal Challenges (2010) 103. See below Part II.

59 IMO Guidelines, IMO Doc MSC 78/26/Add.2 annex 34, annex para 6.5.

60 SOLAS Convention annex ch V reg 33(1-1) and SAR Convention annex para 3.1.9 provide that the party/contracting government 'responsible for the search and rescue region in which such assistance is rendered shall exercise primary responsibility for ensuring such co-ordination and co-operation occurs, so that survivors assisted are disembarked from the assisting ship and delivered to a place of safety, taking into account the particular circumstances of the case and guidelines developed by the Organization' (emphasis added).

61 See, eg, IMO Guidelines, IMO Doc MSC 78/26/Add.2 annex 34, annex paras 2.4, 6.7. 
is capable of safely accommodating the survivors and may serve as a temporary place of safety, it should be relieved of this responsibility as soon as alternative arrangements can be made.

A place of safety may be on land, or it may be aboard a rescue unit or other suitable vessel or facility at sea that can serve as a place of safety until the survivors are disembarked to their next destination.

The Conventions, as amended, indicate that delivery to a place of safety should take into account the particular circumstances of the case. These circumstances may include factors such as the situation on board the assisting ship, on scene conditions, medical needs, and availability of transportation or other rescue units. Each case is unique, and selection of a place of safety may need to account for a variety of important factors.

\section{(iv) Duty to deliver persons rescued at sea to a place of safety?}

Before I examine the concept of place of safety in more detail, the question whether the SOLAS and SAR Conventions actually impose a duty to deliver persons rescued at sea to a place of safety merits discussion. Proelss has argued that the SAR Convention does not entail a duty to deliver persons rescued at sea to a place of safety. ${ }^{62}$ The basic outline of the argument is that neither the definition of 'rescue' in the SAR Convention nor the provision that requires the parties to rescue those in distress at sea entails a duty to deliver rescued persons to a place of safety, because the definition of 'rescue' is found in a non-operative chapter, ${ }^{63}$ and the provision requiring the parties to rescue those in distress at sea does not refer to 'rescue' but to 'assistance'. ${ }^{64}$ Proelss argues that "[b]y using the term "assistance" instead of "rescue", this article avoids incorporating the place of safety criterion ... [and the] same applies with regard to art 2.1.1 Annex [of the] SAR Convention, which, again, obliges States parties only to "take urgent steps to ensure that the necessary assistance is provided”“ ${ }^{65}$ However, in my understanding, this terminological inconsistency does not mean that there is no duty to deliver persons rescued at sea to a place of safety under the SAR Convention. To the contrary, para 3.1.9 in the annex of the SAR Convention explicitly requires the party responsible for the search and rescue region to ensure that survivors are disembarked from the assisting ship and delivered to a place of safety. ${ }^{66}$ This understanding also

Proelss, above n 24, 14-21.

SAR Convention annex para 1.3.2 ('terms and definitions').

64 Ibid annex para 2.1.10 provides: 'Parties shall ensure that assistance be provided to any person in distress at sea. They shall do so regardless of the nationality or status of such a person or the circumstances in which that person is found'.

65 Proelss, above n 24, 17.

66 SAR Convention annex para 3.1.9 provides: 'The Party responsible for the search and rescue region ... shall exercise primary responsibility for ensuring ... that survivors assisted are disembarked from the assisting ship and delivered to a place of safety'. 
corresponds to the preamble to the 2004 amendments, ${ }^{67}$ and the IMO Guidelines on the Treatment of Persons Rescued at Sea, which clearly assume the existence of a duty to deliver survivors to a place of safety. ${ }^{68}$ Accordingly, it is reasonable to believe that the SAR Convention entails a duty to deliver persons rescued at sea to a place of safety. For basically the same reasons, the SOLAS Convention should also be understood in this way. ${ }^{69}$

\section{(c) Interpretation of treaties}

The basic rules on interpretation of treaties are found in arts 31-2 of the VCLT, which are generally assumed to reflect customary international law. ${ }^{70} \mathrm{~A}$ distinction is made between primary and supplementary means of interpretation.

\section{(i) Primary means of interpretation}

The general rule of interpretation is set out in art 31 of the VCLT. It reads:

1. A treaty shall be interpreted in good faith in accordance with the ordinary meaning to be given to the terms of the treaty in their context and in the light of its object and purpose.

2. The context for the purpose of the interpretation of a treaty shall comprise, in addition to the text, including its preamble and annexes:

(a) any agreement relating to the treaty which was made between all the parties in connection with the conclusion of the treaty;

(b) any instrument which was made by one or more parties in connection with the conclusion of the treaty and accepted by the other parties as an instrument related to the treaty.

3. There shall be taken into account, together with the context:

(a) any subsequent agreement between the parties regarding the interpretation of the treaty or the application of its provisions;

672004 Amendments to the SAR Convention, IMO Doc MSC 78/26/Add.1 annex 5, Preamble para 8 states: 'the intent of paragraph $3.1 .9 \ldots$ is to ensure that in every case a place of safety is provided within a reasonable time'.

68 See, eg, IMO Guidelines, IMO Doc MSC 78/26/Add.2 annex 34, annex paras 1.2, 6.15.

69 The existence of a duty to deliver to a place of safety is not the same as the existence of a duty to disembark in any particular state (eg, state of embarkation, state of rescue), which is not supported by international maritime rescue law.

70 The International Court of Justice ('ICJ') has repeatedly reaffirmed that VCLT arts 31-2 reflect customary international law. See, eg, Maritime Dispute (Peru v Chile) (Judgment) [2014] (International Court of Justice, General List No 137, 27 January 2014) 26 [57]; Oil Platforms (Islamic Republic of Iran v United States of America) (Judgment) [2003] ICJ Rep 161, 25 [41]. See also Martti Koskenniemi, Chairman, Report of the Study Group on Fragmentation of International Law: Difficulties Arising from the Diversification and Expansion of International Law, UN Doc A/58/10 (5-9 May 2003) 215 [427] and further references there. 
(b) any subsequent practice in the application of the treaty which establishes the agreement of the parties regarding its interpretation;

(c) any relevant rules of international law applicable in the relations between the parties.

4. A special meaning shall be given to a term if it is established that the parties so intended.

The general rule of interpretation comprises three primary means of interpretation: text, context and object and purpose. There is no hierarchy between the primary means of interpretation. ${ }^{71}$ The means referred to as object and purpose was thus intended to be of equally obligatory character as the text and the context. ${ }^{72}$ The reason for grouping the elements referred to in art 31(3) in the same paragraph was that they are all extrinsic to the text. ${ }^{73}$ Interpretation in the light of the object and purpose is limited by the text of the treaty itself, so as 'one of the (originally many possible) meanings will eventually prevail'. 74

Article 31(3)(c) of the VCLT adds a third element to be taken into account together with the context: 'any relevant rules of international law applicable in the relations between the parties'. The basic meaning is that a treaty must be interpreted in the wider context of international law - systemic integration. ${ }^{75}$ Although this could seem obvious, systemic integration is presumably the most intricate of all elements of

71 The ILC emphasised that the application of the elements of interpretation in VCLT art 31 would be a single combined operation, as indicated by the heading 'General rule' in the singular. The intention was that '[a]ll the various elements, as they were present in any given case, would be thrown into the crucible, and their intention would give the legally relevant interpretation'. According to the ILC it was 'considerations of logic, not any obligatory legal hierarchy, which guided the Commission in arriving at the arrangement': International Law Commission, 'Report of the International Law Commission on the Work of its Eighteenth Session' [1966] 2 Yearbook of the International Law Commission, 219-20 [8]-[9]. But see Aust who means that 'although [VCLT art 31(1)] contains both the textual (or literal) and the effectiveness (or teleological) approaches, it gives precedence to the textual': Anthony Aust, Modern Treaty Law and Practice ( $3^{\text {rd }}$ ed, 2013) 208 and further references there. See also Ulf Linderfalk, On the Interpretation of Treaties (Springer, 2007) 343-8.

72 The ILC emphasised that the elements referred to in VCLT art 31(3) 'are all of an obligatory character and by their very nature could not be considered to be norms of interpretation in any way inferior to norms those which precede them': International Law Commission, 'Report of the International Law Commission on the Work of its Eighteenth Session', above n 71, 220 [9].

73 The ILC emphasised the obligatory character of these elements, stating that 'the logical consideration ... is that these elements are extrinsic to the text. But these three elements are all of an obligatory character and by their very nature could not be considered to be norms of interpretation in any way inferior to those which precede them': ibid 220 [9].

74 Mark Eugen Villiger, Commentary on the 1969 Vienna Convention on the Law of Treaties (Brill, 2009) 428.

75 Aust, above n 71, 216. 
interpretation. Any rule that springs from the formal sources of international law may be taken into account. ${ }^{76}$ However, not all rules of international law may be taken into account, but only rules that are 'relevant' and 'applicable in the relations between the parties'. ${ }^{77}$ Rules that only apply to some of the parties may thus not be taken into account. Hence, in art 31(3)(c) of the VCLT, 'parties' shall be read as 'all the parties to the treaty'. ${ }^{78}$ This limitation is naturally more important in relation to rules of treaties than to customary rules, since customary rules are generally universally applicable. However, in considering whether a rule is applicable it needs to be borne in mind that treaties may reflect customary international law that applies between the parties. ${ }^{79}$

76 The reference to 'rules of international law' corresponds with the notion of the sources of international law set out in the Statute of the International Court of Justice art 38(1): Villiger, above n 74, 433. See also Linderfalk, above n 71, 177; Koskenniemi, above n 70, 217 [426].

77 VCLT art 31(3)(c) (emphasis added). Linderfalk means that a rule is to be considered relevant 'if (and only if) it governs the state of affairs, in relation to which the interpreted treaty is examined': Linderfalk, above n 71, 178.

78 This point was highlighted by a panel of the World Trade Organization ('WTO') in the ECBiotech case. In interpreting VCLT art 31(3)(c) the panel noted that it does not refer to 'one or more parties' or to 'the parties to the dispute' and that VCLT art 2(1)(g) defines 'party' as 'a State which has consented to be bound by the treaty and for which the treaty is in force'. The panel reasoned that '[i]t may be inferred from these elements that the rules of international law applicable in the relations between "the parties" are the rules of international law applicable in the relations between the States which have consented to be bound by the treaty which is being interpreted, and for which that treaty is in force'. That is, all the parties to the treaty being interpreted: Panel Report, European CommunitiesMeasures Affecting the Approval and Marketing of Biotech Products, WTO Doc WT/DS291-293/R (29 September 2006) 333 [7.68]. For further comments on the case, see Koskenniemi, above n 70, 227 [448].

79 This can be illustrated by reference to an article in which Noll criticises Bethlehem and Lauterpacht for taking into account the International Covenant on Civil and Political Rights, opened for signature 19 December 1966, 999 UNTS 171 (entered into force 23 March 1976) ('ICCPR') and the Convention for the Protection of Human Rights and Fundamental Freedoms, opened for signature 4 November 1950, 213 UNTS 222 (entered into force 3 September 1953) ('ECHR') - as elements of interpretation within the meaning of VCLT art 31(3)(c) - in an interpretation of the non-refoulement obligation of the Convention Relating to the Status of Refugees, opened for signature 28 July 1951, 189 UNTS 137 (entered into force 22 April 1954) ('Refugee Convention'). According to Noll, the interpretation is methodologically flawed since 'the group of states bound by the [Refugee Convention] is not coextensive with either the group bound by the ICCPR or the group bound by the ECHR': Gregor Noll, 'Seeking Asylum at Embassies: A Right to Entry under International Law?’ (2006) 17 International Journal of Refugee Law 542, 552 n 39. However, given that the rules governing the extraterritorial applicability of the ICCPR and the ECHR may have customary status, and as such apply to all the parties to the Refugee Convention, it may be correct to take into account the geographical applicability of the $I C C P R$ and the ECHR in the interpretation of the geographical applicability of the nonrefoulement obligation of the Refugee Convention. 
The heart of the difficulties associated with art 31(3)(c) of the VCLT lies in its function as an expression for the objective of systemic integration, that is, 'the process ... whereby international obligations are interpreted by reference to their normative environment'. ${ }^{80}$ This feature was highlighted in the Oil Platforms case. ${ }^{81}$ The central question of the case was whether the United States of America, by conducting a number of attacks on Iranian oil platforms in the Persian Gulf during the so-called Tanker War in the 1980s, had violated a rule concerning freedom of commerce and navigation in the Treaty of Amity, Economic Relations, and Consular Rights, United States of AmericaIran. ${ }^{82}$ The Court found that the United States had not. ${ }^{83}$ Nevertheless, the Court carefully examined a defence invoked by the United States, namely that the actions complained of by Iran were justified under another rule of the treaty which provided that ' $[t]$ he present Treaty shall not preclude the application of measures ... necessary to fulfil the obligations of a High Contracting Party for the maintenance or restoration of international peace and security, or necessary to protect its essential security interests'. ${ }^{84}$ For the purpose of interpreting that rule the Court declared that,

under the general rules of treaty interpretation, as reflected in the [VCLT], interpretation must take into account "any relevant rules of international law applicable in the relations between the parties” (Art. 31, para. 3 (c)). The Court cannot accept that [the rule subject to interpretation] was intended to operate wholly independently of the relevant rules of international law on the use of force, so as to be capable of being successfully invoked, even in the limited context of a claim for breach of the Treaty, in relation to an unlawful

80 Koskenniemi, above n 70, 207 [412].

81 Oil Platforms [2003] ICJ Rep 161; See also Legal Consequences for States of the Continued Presence of South Africa in Namibia (South West Africa) Notwithstanding Security Council Resolution 276 (1970) (Advisory Opinion) [1971] ICJ Rep 16, 31 [53] in which the ICJ held that 'an international instrument has to be interpreted and applied within the framework of the entire legal system prevailing at the time of interpretation'; See also Case concerning Right of Passage over Indian Territory (Portugal v India) (Preliminary Objections) (Judgment) [1957] ICJ Rep 125, 142 in which the ICJ stated that '[i]t is a rule of interpretation that a text emanating from a Government must, in principle, be interpreted as producing and as intended to produce effects in accordance with existing law and not in violation of it'.

82 Treaty of Amity, Economic Relations, and Consular Rights, United States of America-Iran (15 August 1955), 284 UNTS 93 art X(1) ('US-Iran Treaty of Amity') which reads: 'Between the territories of the two High Contracting Parties there shall be freedom of commerce and navigation'. The factual background of the case is set out in Oil Platforms [2003] ICJ Rep 161, 174-6 [23]-[25].

83 The principal reason was that there was at the time of the attacks no commerce between the territories of Iran and the United States in respect of oil produced from the attacked platforms. The attacks could therefore not be said to have infringed the freedom of commerce in oil between the parties, which was protected under the relevant treaty. Oil Platforms [2003] ICJ Rep 161, 207 [98].

84 Ibid 178-9 [32]; US-Iran Treaty of Amity art XX(1)(d). 
use of force. The application of the relevant rules of international law relating to his question thus forms an integral part of the task of interpretation entrusted to the Court. ${ }^{85}$

After a lengthy assessment of the conditions of legitimate self-defence under international law, the Court concluded that,

the actions carried out by the United States ... cannot be justified ... as being measures necessary to protect the essential security interests of the United States, since those actions constituted recourse to armed force not qualifying, under international law on the question, as acts of self-defence, and thus did not fall within the category of measures contemplated $\ldots$ by that provision of the Treaty. 86

The judgment was supported by a large majority of the judges, but different views on the question of treaty interpretation were expressed in separate opinions. The judgment has been criticised, primarily on arguments that the jurisdiction of the Court was limited to pronouncing upon the rule concerning freedom of commerce and navigation, and not the international law on the use of force. ${ }^{87}$ Nevertheless, Oil Platforms is a firm acknowledgment of the significance of systemic integration in treaty interpretation. However, the judgment provides little clarification as to how to practically apply systemic integration. ${ }^{88}$

85 Oil Platforms [2003] ICJ Rep 161, 182 [41].

86 Ibid 199 [78].

87 See, eg, Aust, above n 68, 216: Aust refers to the judgment as a misunderstanding of VCLT art 31(3)(c) and notes, drawing on the separate opinion of Judge Higgins, that the Court 'used [art 31(3)(c)] as a peg on which to hang the whole corpus of international law on the use of force'. In her separate opinion, Judge Higgins also pointed out the need to interpret the rule in accordance with the ordinary meaning of the terms and in its context which, in her view, was 'clearly that of an economic and commercial treaty'. In critical words, she argued that the 'Court has ... not interpreted [the rule] by reference to the rules on treaty interpretation [but] rather invoked the concept of treaty interpretation to displace the applicable law': Oil Platforms [2003] ICJ Rep 161, 237 [46], 238 [49], 240 [54] (Higgins J). See also Rosalyn Higgins, 'A Babel of Judicial Voices? Ruminations from the Bench' (2006) 55 International and Comparative Law Quarterly 791, 802-3.

88 For further comments on the case, see Koskenniemi, above n 70, 228-32 [451]-[460]; Villiger, above $n$ 74, 434. In the Final Report of the ILC Study Group on Fragmentation of International Law, it is argued that it may have been unnecessary for the ICJ to have recourse to VCLT art 31(3)(c) in Oil Platforms, since the treaty rule subject to interpretation contained the term 'necessary' which required interpretation. Koskenniemi suggests that '[a]bsent the possibility of using a documented party intent to elucidate it, the Court could simply have turned to what "general international law" said on the content of that standard'. The rationale for this, he means, would be the universal character of customary international law; Koskenniemi, above n 70, 232 [459].What Koskenniemi seems to imply is that the ICJ and other international courts habitually have taken into account customary international law and general principles of international law as lex generalis when dealing with any particular agreement, notwithstanding any limitation of the jurisdiction of the court, and that the ICJ simply could have done so in Oil Platforms - without explicitly 
The 'principle of systemic integration' was also the subject of much attention by the ILC in its work on fragmentation of international law, in which the ILC sought to examine whether international law itself - and in particular the rules on interpretation of treaties - would not solve the problems of substantive fragmentation of international law. ${ }^{89}$ The ILC Study Group laid particular emphasis on the lex specialis and lex posterior maxims and the systemic character of international law. Of particular interest to this article is the emphasis laid on systemic integration as a potential cure for fragmentation. The Study Group even went as far as saying that ' $[w]$ ithout the principle of "systemic integration" it would be impossible to give expression to and to keep alive, any sense of the common good of humankind, which is not reducible to the good of any particular institution or regime". ${ }^{90}$ Similar to the Oil Platforms case, the work by the ILC is an important acknowledgement of the importance of systemic integration in treaty interpretation, but leaves many practical questions unanswered.

(ii) Supplementary means of interpretation

Article 32 of the VCLT concerns travaux préparatoires and other supplementary means of interpretation. It reads:

Recourse may be had to supplementary means of interpretation, including the preparatory work of the treaty and the circumstances of its conclusion, in order to confirm the

referring to systemic integration. However, in my understanding, it is difficult to see how any material external to the treaty could have been integrated in the interpretation without having resort to systemic integration (or any of the other elements referred to in VCLT art 31(3)).

89 The concern about fragmentation of international law can be summarised as 'the rise of specialized rules and rule-systems that have no clear relationship to each other', comprising both substantive and institutional aspects. At an institutional level, the concern relates to the plurality of courts and other implementation organs, and the risk for conflicting jurisprudence and forum-shopping. The substantive aspects relate to "the emergence of "special laws", treaty-regimes, and functional clusters of rules and specialized branches of international law and on their relationship inter se and to general international law'. Koskenniemi, above n 70, 245 [483], 247 [489].

90 Ibid 244 [480]. See Higgins, above n 84, 803-4: Higgins is sceptical to VCLT art 31(3)(c) as the overall answer to systemic fragmentation because she suspect that 'invocation of this provision brings with it as many problems as it resolves'. For the concept of so-called selfcontained regimes, see Martti Koskenniemi, 'Outline of the Chairman of the ILC Study Group on Fragmentation of International Law: The Function and Scope of the Lex Specialis Rule and the Question of "Self-Contained Regimes" (2003) $<$ http://legal.un.org/ilc/sessions/55/pdfs/fragmentation_outline.pdf>, which states that '[a] regime is a union of rules laying down particular rights, duties and powers and rules having to do with the administration of such rules, including in particular rules for reacting to breaches. When such a regime seeks precedence in regard to the general law, we have a "self-contained regime”, a special case of lex specialis'. See also Koskenniemi, above n 70, 216. 
meaning resulting from the application of article 31, or to determine the meaning when the interpretation according to article 31:

(a) leaves the meaning ambiguous or obscure; or

(b) leads to a result which is manifestly absurd or unreasonable. ${ }^{91}$

This makes it clear that the primary purpose of treaty interpretation is not to ascertain what the parties intended at the time of the conclusion of the treaty, but instead to construe the meaning of the treaty itself. ${ }^{92}$ Consequently, travaux préparatoires, the circumstances of the conclusion of the treaty and other supplementary means of interpretation, ${ }^{93}$ which might be expressive of the intention of the parties, may only be used for the interpretation of a treaty for three purposes: (i) 'to confirm the meaning resulting from the application of [the general rule of interpretation]', (ii) 'to determine the meaning when the interpretation according to [the general rule of interpretation] ... leaves the meaning ambiguous or obscure', (iii) 'to determine the meaning when the interpretation according to [the general rule of interpretation] ... leads to a result which is manifestly absurd or unreasonable'. 94

\section{PART II - INTERPRETATION OF THE CONCEPT OF PLACE OF SAFETY}

The concept of 'place of safety' is found in paras 1.3.2 and 3.1.9 in the annex to the SAR Convention and in reg 33(1-1) in ch V of the annex to the SOLAS Convention. The

91 VCLT art 32.

92 International Law Commission, 'Report of the International Law Commission on the Work of its Eighteenth Session’, above n 71, 223 [18].

93 That supplementary means of interpretation is not limited to travaux préparatoires and the circumstances at the time of the conclusion of the treaty, is evident from the use of the word 'including' in VCLT art 32. Linderfalk advocates a broad understanding of travaux préparatoires, including 'all ... representations produced in the preparation for the establishing of the treaty as definite', and the circumstances at the time of the conclusion of the treaty, including 'any state-of-affairs, whose existence at least partly caused the conclusion of the treaty': Linderfalk, above n 71, 245, 249. Similarly, Aust states that 'the travaux ... is generally understood to include written material, such as successive drafts of the treaty, conference records, explanatory statements by an expert consultant at a codification conference, uncontested interpretation statements by the chairman of a drafting committee and ILC Commentaries': Aust, above n 71, 218. As regards other possible supplementary means of interpretation, Linderfalk discusses ratification work, treaties in pari materia and the context (without having to be confined to the limits set by the ordinary meaning, as required when used as a primary means of interpretation): Linderfalk, above $n$ 71, 238-65. Aust also includes common legal techniques, such as é contrario, ejusdum generis, lex posterior derogat legi priori and lex specialis derogat legi generali, as other possible aids of interpretation. Furthermore, Aust notes that '[i]t is also legitimate to assume that the parties to a treaty did not intend that it would be incompatible with customary international law': Aust, above n 71, 220-1. 
ordinary meaning of the term is not entirely clear. While the word 'place' is relatively clear, the word 'safety' is open-ended in character. 95 'Place of safety' can mean either a place where it is safe in general or a place where it is safe from some perils (but not from others). In the former sense, the phrase 'place of safety' encompasses safety from any peril, including for example, the risk of persecution. Whereas in the latter sense, it only encompasses safety from particular perils; such as the risk of drowning. The meaning of the term is moreover neither clear in any of the other translations of the SOLAS and SAR Conventions. ${ }^{96}$

Neither the SOLAS Convention nor the SAR Convention provide specific rules for their interpretation. Accordingly, the general rules on the interpretation of treaties apply. Both the SOLAS Convention and the SAR Convention are 'international agreements concluded between States in written form and governed by international law', and are so treaties as defined in art 2(1)(a) of the VCLT. However, they were both adopted before the VCLT entered into force, and so in accordance with art 4 of that treaty, the VCLT itself is not applicable to the both conventions. ${ }^{97}$ However, the rules on interpretation of treaties set forth in the VCLT reflect customary rules in force at the time of the conclusion of the SOLAS and SAR Conventions.

An important standard for the interpretation of treaties is that terms and expressions used several times in a treaty may be deemed to bear a uniform meaning. ${ }^{98}$ This indicates that the phrase 'place of safety' should be deemed to have the same meaning in the SAR Convention and the SOLAS Convention. Arguably, the meaning of the former may be understood as a contextual element in the interpretation of the latter and vice versa. 99

\section{(a) Text}

The words 'place of safety' do not provide much guidance on the meaning of the concept. According to the Oxford Dictionary of English 'place' means 'a particular position, point, or area in space; a location', while 'safety' means 'the condition of

95 For the ordinary meaning of the terms 'place' and 'safety', see below Part II(a).

96 The SOLAS and SAR Conventions are established in the Chinese, English, French, Russian and Spanish languages, each text being equally authentic: SOLAS Convention art XIII; SAR Convention art VIII. See below Part II(a) for the French and Spanish wording of the concept of 'place of safety'.

97 VCLT art 4: 'Without prejudice to the application of any rules set forth in the present Convention to which treaties would be subject under international law independently of the Convention, the Convention applies only to treaties which are concluded by States after the entry into force of the present Convention with regard to such States'.

Linderfalk, above n 71, 106-7.

99 See below Part II(b). 
being protected from or unlikely to cause danger, risk, or injury' ${ }^{100}$ However, it is not clear in relation to what dangers, risks, or injuries the protection shall exist. Neither do the equally authoritative French ('lieu sûr') and Spanish ('lugar seguro') translations provide any clearer meaning. Still, the text sets the limits to which the meaning resulting from the application of the other primary means of interpretation must be confined.

\section{(b) Context}

The context of the concept of place of safety comprises, first, the texts of the SOLAS and $S A R$ Conventions, including their preambles and annexes. While the original preambles are rather rudimentary, drawing basically on the duty to rescue persons in distress at sea, international co-operation and the needs of maritime traffic for the rescue of persons in distress at sea. ${ }^{101}$ The preambles of the 2004 amendments are more important in that they clarify who bears the responsibility to arrange for a 'place of safety' - namely, the party responsible for the search and rescue region in which the survivors were recovered. ${ }^{102}$ The objectives are further elucidated by provisions using the phrase 'place of safety'. For example, some apparent objectives are for 'masters of ships providing assistance by embarking persons in distress at sea... [to be] released from their obligations with minimum further deviation from the ship's intended voyage' and for the 'relevant Parties to 'arrange for ... disembarkation....as soon as reasonably practicable'. ${ }^{103}$ These remarks are of considerable importance for the interpretation. In most cases, there is not merely one location, but several, that could qualify as a 'place of safety'. However, the list of possible locations is effectively limited by the objective to disembark persons as soon as possible and to minimise further deviation from the ship's intended voyage. ${ }^{104}$

Furthermore, the SOLAS and SAR Conventions refer to 'the particular circumstances of the case and guidelines developed by the Organization' for the purpose of

100 Angus Stevenson (ed), Oxford Dictionary of English (Oxford University Press, $3^{\text {rd }}$ ed, 2010).

101 SOLAS Convention Preamble paras 2-3; SAR Convention Preamble paras 2-5.

1022004 Amendments to the SOLAS Convention, IMO Doc MSC 78/26/Add.1 annex 3, Preamble para 8; 2004 Amendments to the SAR Convention, IMO Doc MSC 78/26/Add.1 annex 5, Preamble para 8.

103 SOLAS Convention annex ch V reg 33(1-1); SAR Convention annex para 3.1.9.

104 Other practically relevant considerations include the obligation of shipmasters to treat rescued persons with humanity, and the obligation of '[t]he owner, the charterer, the company operating the ship ... or any other person ... not [to] prevent or restrict the master of the ship from taking or executing any decision which, in the master's professional judgement, is necessary for safety of life at sea': SOLAS Convention annex ch V regs 33(6), 34-1. 
interpreting the concept of place of safety. ${ }^{105}$ The reference to 'the particular circumstances of the case' underlines that the meaning of the concept must not be determined in abstracto and gives the applier the flexibility to address each situation on a case-by-case basis. ${ }^{106}$ The reference to 'guidelines developed by the Organization' refers to the IMO Guidelines on the Treatment of Persons Rescued at Sea. ${ }^{107}$ The guidelines provide important material for interpretation. First, they reiterate the intent of the provisions comprising the concept of 'place of safety' — 'to ensure that in every case a place of safety is provided within a reasonable time' — and to point out who bears the responsibility for this obligation — 'the Contracting Government/Party responsible for the SAR region in which the survivors were recovered'. ${ }^{108}$ With regard to the meaning of the concept, the guidelines make it clear that a 'place of safety' is a location 'where rescue operations are considered to terminate'; 'where the survivors' safety of life is no longer threatened'; where 'their basic human needs (such as food, shelter and medical needs) can be met': and 'from which transportation arrangements can be made for the survivors' next or final destination'. ${ }^{109}$ It is clarified that a 'place of safety may be on land, or it may be aboard a rescue unit or other suitable vessel or facility at sea', 110 but that an assisting ship should not be considered a 'place of safety' 'based solely on the fact that the survivors are no longer in immediate danger once aboard the ship' ${ }^{111}$ Furthermore, it is made clear that the delivery to a 'place of safety' should take into account 'factors such as the situation on board the assisting ship, on scene conditions, medical needs, and availability of transportation or other rescue units,' 112 and that '[t]he need to avoid disembarkation in territories where the lives and freedoms of those alleging a well-founded fear of persecution would be threatened is a consideration in the case of asylum-seekers and refugees recovered at sea'.113

In addition to the text, including its preamble and annexes, the context for the purpose of interpretation of a treaty comprises 'any agreement relating to the treaty

105 SOLAS Convention annex ch V reg 33(1-1); SAR Convention annex para 3.1.9.

See especially IMO Guidelines, IMO Doc MSC 78/26/Add.2 annex 34, annex para 2.6.

107 Ibid Preamble para 8.

108 Ibid Preamble para 9, annex para 2.5.

109 Ibid annex para 6.12.

110 Ibid annex para 6.14 .

111 Ibid annex para 6.13.

112 Ibid annex para 6.15.

113 Ibid annex para 6.17. Somewhat curiously, certain aspects set out in the annex to the guidelines are repeated in an appendix ('Some Comments on Relevant International Law'). The appendix includes comments on the duty to rescue persons in distress at sea, the application of the SOLAS Convention on ships carrying rescued persons, states' territorial sovereignty and the non-refoulement obligation of the Refugee Convention. The legal value of the appendix is, if any, unclear. 
which was made between all the parties in connection with the conclusion of the treaty' and 'any instrument which was made by one or more parties in connection with the conclusion of the treaty and accepted by the other parties as an instrument related to the treaty'. ${ }^{114}$ Admittedly, the 2004 Amendments to the SAR Convention are part of the relevant context within the meaning of art 31(2)(b) of the VCLT for the interpretation of the concept of 'place of safety' in the SOLAS Convention - and vice versa. Both the 2004 Amendments to the SAR Convention and the 2004 Amendments to the SOLAS Convention were adopted in connection with each other. However, they were not adopted by the same parties. Both instruments were adopted on 20 May 2004 by the Maritime Safety Committee of the IMO acting as an agent on behalf of the parties to the SOLAS and SAR Conventions. ${ }^{115}$ Since both conventions bind different parties, the instruments cannot be seen as contextual elements within the meaning of art 31(2)(a) of the VCLT. ${ }^{116}$ Still, both instruments were adopted in connection with each other. What remains to be considered, in order to classify them as contextual elements within the meaning of art 31(2)(b) of the VCLT, is if they were 'accepted by the other parties as an instrument related to the treaty', that is, if the 2004 Amendments to the SAR Convention were accepted by the parties to the 2004 Amendments to the SOLAS Convention as a related instrument. This must have been the case. As recognised in their preambles, both instruments were adopted in response to the same resolution of the Assembly of the IMO. Moreover, the preambles of both instruments are matching in substance and the provisions including the phrase 'place of safety' are identical. Both instruments were also adopted following joint preparation and adoption procedures. ${ }^{117}$ For these reasons, it is reasonable to believe that the 2004 amendments are contextual elements for the interpretation of each other - thus indicating that the concept of place of safety

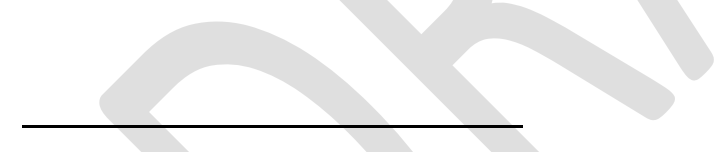

114 VCLT arts 31(2)(a)-(b).

115 See, eg, Convention on the International Maritime Organization, opened for signature 6 March 1948, 289 UNTS 4 (entered into force 17 March 1958) art 28(2) which provides that '[t]he Maritime Safety Committee shall provide machinery for performing any duties assigned to it by this Convention, the Assembly or the Council, or any duty within the scope of this Article which may be assigned to it by or under any other international instrument and accepted by the Organization' (emphasis added).

$116 V C L T$ art 31(2)(a) refers to, 'any agreement relating to the treaty which was made between all the parties in connection with the conclusion of the treaty' (emphasis added).

117 See, eg, Report of the Maritime Safety Committee on its Seventy-Eight Session, MSC, 78 ${ }^{\text {th }}$ sess, Agenda Item 26, IMO Doc MSC 78(26) (4 June 2004) 112-13 [16.46]-[16.56]; Report to the Maritime Safety Committee, Sub-Committee on Radiocommunications and Search and Rescue, $8^{\text {th }}$ sess, Agenda Item 18, IMO Doc COMSAR 8/18 (26 February 2004) 18, annex 10; Report of the Maritime Safety Committee on its Seventy-Seventh Session, MSC, $77^{\text {th }}$ sess, Agenda Item 26, IMO Doc MSC 77/26 (10 June 2003) 77-9 [10.26][10.37]. 
has the same meaning in the SOLAS Convention as in the SAR Convention. This understanding is also supported by the travaux préparatoires. ${ }^{118}$

\section{(c) Object and purpose}

The SOLAS Convention was adopted in a desire to promote safety of life at sea by establishing uniform principles and rules directed thereto. ${ }^{119}$ The objective of the SAR Convention is to ensure that no matter where a distress at sea situation occurs, rescue operations will be co-coordinated by a search and rescue ('SAR') organization and, when necessary, by cooperation between neighbouring SAR organizations. ${ }^{120}$ Importantly, the preambles of the 2004 amendments set out that the intent of the disembarkation rules 'is to ensure that in every case a place of safety is provided within reasonable time [and] that the responsibility to provide a place of safety, or to ensure that a place of safety is provided, falls on the Party responsible for the SAR region in which the survivors were recovered'. ${ }^{121}$

There shall be taken into account, together with the context, any subsequent agreement, practice and any relevant rules of international law applicable in the relations between the parties. ${ }^{122}$ As concerns the concept of 'place of safety', it is primarily the last element that is important. This is because there is no subsequent agreement or practice within the meaning of arts 31(3)(a)-(b) of the VCLT regarding the concept of 'place of safety'. Although the concept surely has been applied many times, this subsequent practice cannot be considered to be sufficiently consistent and accepted so that it establishes an agreement between all the parties bound by the disembarkation rules. Neither is there any subsequent agreement between all the parties to the SOLAS and SAR Conventions regarding the meaning of the concept. Consequently, systemic integration is of significant importance to the interpretation. What follows is a summary of some rules of international law that require consideration in the interpretation. These rules are international human rights law, international refugee law and international law against transnational organised crime.

118 See, eg, Report to the Maritime Safety Committee, Sub-Committee on Radiocommunications and Search and Rescue, $7^{\text {th }}$ sess, Agenda Item 22, IMO Doc COMSAR 7/23 (20 February 2003) 29 [8.25] in which it was recognized that 'the new proposed paragraph 3.1.9 of the Annex to the SAR Convention contained the same provision as new SOLAS regulation V/33.1bis as adjusted for the purpose'.

119 SOLAS Convention Preamble para 1.

120 See, eg, SAR Convention Preamble, annex paras 2.1.1, 3.1.1.

1212004 Amendments to the SOLAS Convention, IMO Doc MSC 78/26/Add.1 annex 3, Preamble para 8; 2004 Amendments to the SAR Convention, IMO Doc MSC 78/26/Add.1 annex 5, Preamble para 8.

122 VCLT art 31(3)(c). 


\section{(i) International human rights law}

International human rights law is the body of international law concerned with the rights of individuals and groups of individuals (human rights). It is a rule-complex which - similar to any other dedicated and functionally limited body of international law (such as the law of the sea) - may be referred to as a 'specialised regime' in that it has its own principles, objectives (ethos) and institutions. Nevertheless, neither international human rights law nor any other specialised regime of international law exists and operates in isolation from other branches of international law. International law is a legal system and its rules exist and operate in relation to each other. Hence, it is not surprising that an array of human rights may be relevant to the treatment and disembarkation of persons rescued at sea. ${ }^{123}$ What follows is an exemplifying yet inconclusive discussion of some fundamental rights that may require consideration in the interpretation of the concept of 'place of safety'.

The right to life is 'basic to all human rights' 124 and was considered by the drafters of the International Covenant on Civil and Political Rights as 'the most fundamental of all rights'. ${ }^{125}$ The right to life is set out in the UDHR, ${ }^{126}$ and the ICCPR. ${ }^{127}$ It is also set out in regional treaties, such as the ECHR, ${ }^{128}$ the American Convention on Human

123 Examples of human rights that may require consideration in situations when persons are to be disembarked following rescue at sea include, inter alia, the right to health: Universal Declaration of Human Rights, GA Res 217A (III), UN GAOR, $3^{\text {rd }}$ sess, $183^{\text {rd }}$ plen mtg, UN Doc A/810 (10 December 1948) art 25 ('UDHR'); International Covenant on Economic, Social and Cultural Rights, opened for signature 16 December 1966, 993 UNTS 3 (entered into force 3 January 1976) art 12 ('ICESCR'); the right to food and housing: UDHR art 25; ICESCR art 11; as well as rights of certain categories of persons: See, eg, Convention on the Rights of Persons with Disabilities, opened for signature 13 December 2006, 2515 UNTS 3 (entered into force 3 May 2008) ('CRPD'); Convention on the Elimination of All Forms of Discrimination against Women, opened for signature 18 December 1979, 1249 UNTS 13 (entered into force 3 September 1981) ('CEDAW'); Convention on the Rights of the Child, opened for signature 20 November 1989, 1577 UNTS 3 (entered into force 2 September 1990 ('CRC').

124 Human Rights Committee, General Comment No 14, The Right to Life (1985) art 6(1) in Human Rights Instruments, Compilation of General Comments and General Recommendations Adopted by Human Rights Treaty Bodies, UN Doc HRI/GEN/1/Rev.9 (Vol. I).

125 Marc J Bossuyt, Guide to the “Travaux Préparatoires” of the International Covenant on Civil and Political Rights (Kluwer Academic Publishers, 1987) 115.

126 UDHR art 3: '[e]veryone has the right to life, liberty and security of person'.

127 ICCPR art 6(1): '[e]very human being has the inherent right to life. This right shall be protected by law. No one shall be arbitrarily deprived of his life'.

128 ECHR art 2. 
Rights, ${ }^{129}$ and the African Charter on Human and Peoples' Rights, ${ }^{130}$ and in the ASEAN Human Rights Declaration. ${ }^{131}$ The right to life is a broad concept 'which should not be interpreted narrowly' as it 'cannot be properly understood in a restrictive manner'. ${ }^{132}$

Another relevant human right is the right to family unity. Article 23 of the ICCPR recognises the family as the natural and fundamental group unit of society which is entitled to protection by society and the state. Protection of the family and its members is also guaranteed, directly or indirectly, by other provisions of the ICCPR. ${ }^{133}$ The right to family unity is affirmed also in other human rights instruments, including the $U D H R,{ }^{134}$ the ICESCR, ${ }^{135}$ the ECHR, ${ }^{136}$ the ACHR, ${ }^{137}$ the $A H R D,{ }^{138}$ and the $A C H P R .{ }^{139}$ The UNHCR has repeatedly reaffirmed the existence of a right to family unity by stressing state obligations to take measures that respect family unity and family reunion, ${ }^{140}$ particularly in situations where there are large-scale influxes of asylum-seekers. ${ }^{141}$

129 American Convention on Human Rights "Pact of San José, Costa Rica", opened for signature 22 November 1969, 1144 UNTS 143 (entered into force 18 July 1978) art 4 ('ACHR').

130 African Charter on Human and Peoples' Rights, opened for signature 27 June 1981, 1520 UNTS 217 (entered into force 21 October 1986) art 4 ('ACHPR').

131 ASEAN Human Rights Declaration (adopted 18 November 2012) art 11 ('AHRD’).

132 Human Rights Committee, General Comment No. 6: Article 6 (Right to Life), $16^{\text {th }}$ sess (30 April 1982) in Compilation of General Comments and General Recommendations Adopted by Human Rights Treaty Bodies, UN Doc HRI/GEN/1/Rev.9 (Vol. I) (27 May 2008).

133 Human Rights Committee, General Comment No. 19: Article 23 (The Family), 39 ${ }^{\text {th }}$ sess (27 July 1990) [1] in Compilation of General Comments and General Recommendations Adopted by Human Rights Treaty Bodies, UN Doc HRI/GEN/1/Rev.9 (Vol. I) (27 May 2008); See also ICCPR arts 17, 24.

$134 U D H R$ art 16.

135 ICESCR art 10.

136 ECHR art 16.

137 ACHR art 17.

138 AHRD art 19.

139 ACHPR arts 18(1)-(2).

140 UNHCR, Executive Committee, No.1 (XXVIII) Establishment of Sub-Committee and General, $26^{\text {th }}$ sess (14 October 1975); UNHCR, Executive Committee, No. 9 (XXVIII) Family Reunion, 28 ${ }^{\text {th }}$ sess (12 October 1977); UNHCR, Executive Committee, No. 22 (XXXII) Protection of Asylum-Seekers in Situations of Large-Scale Influx, 32 ${ }^{\text {nd }}$ sess (21 October 1981); UNHCR, Executive Committee, No. 88 (L) Conclusions on the Protection of the Refugee's Family, $50^{\text {th }}$ sess (8 October 1999).

141 UNHCR, Executive Committee, No. 22 (XXXII) Protection of Asylum-Seekers in Situations of Large-Scale Influx, $32^{\text {nd }}$ sess (21 October 1981). 
International human rights law also contains many prohibitions of discrimination. Examples include the general prohibition of discrimination, ${ }^{142}$ the prohibition of racial discrimination, ${ }^{143}$ the prohibition of discrimination against women, ${ }^{144}$ the prohibition of discrimination of children, ${ }^{145}$ and the prohibition of discrimination of persons with disabilities. ${ }^{146}$ Notwithstanding their general character, the rules on non-discrimination may be both relevant and applicable, as customary rules, so that they require consideration in the interpretation of the concept of 'place of safety'.

The significance of the right to life for the concept of 'place of safety' is reflected in the description of it as a location where the survivors' lives are no longer threatened and where their basic human needs (such as food, shelter and medical needs) can be met. ${ }^{147}$ The integration of the right to family unity means that members of a migrant family rescued at sea should, in principle, be disembarked at the same 'place of safety'. This is particularly important in the case of children rescued at sea. ${ }^{148}$ The integration of prohibitions of discrimination into the concept of place of safety means that disembarkation that amounts to racial discrimination or any other form of prohibited discrimination cannot constitute delivery to a 'place of safety'.

\section{(ii) International refugee law}

The authority of a state to control its territory is a fundamental aspect of the sovereignty of a state. A state may decide who may enter and remain on its territory. This aspect of state sovereignty is contrasted with the body of international law concerned with the right and protection of refugees - international refugee law.

Article 14(1) of the $U D H R$ states that, '[e]veryone has the right to seek and to enjoy in other countries asylum from persecution'. However, the UDHR is not hard-law conferring legally binding obligations upon states and there is no similar norm in any treaty law with a universal scope. Nor is it likely that art 14(1) of the UDHR reflects customary international law, at least not as concerns the right to enjoy asylum. ${ }^{149}$

142 See, eg, Charter of the United Nations arts 1(3), 55(c), 56; UDHR arts 1, 2, 7; ICCPR art 26.

143 See, eg, International Convention on the Elimination of All Forms of Racial Discrimination, opened for signature 7 March 1966, 660 UNTS 211 (entered into force 4 January 1969) art 2 ('CERD').

144 See, eg, CEDAW art 2.

145 See, eg, $C R C$ art 2.

146 See, eg, $C R P D$ art 5.

147 IMO Guidelines, IMO Doc MSC 78/26/Add.2 annex 34, annex para 6.12.

148 Cf $C R C$ art 9(1) which provides that, 'States Parties shall ensure that a child shall not be separated from his or her parents against their will'.

149 Even if a right to seek asylum may exist under customary international law it is not likely that there is a customary duty of states to grant asylum other than under the principle of 
Instead, the principal protection mechanism under international refugee law is more narrowly construed, as an obligation of states to avoid sending refugees back to their persecutors (non-refoulement). The principle of non-refoulement is the overarching aim of the asylum regime and 'the cornerstone of asylum and of international refugee law'. 150 The Refugee Convention sets out the principle of non-refoulement in art 33(1):

No Contracting State shall expel or return ('refouler') a refugee in any manner whatsoever to the frontiers of territories where his life or freedom would be threatened on account of his race, religion, nationality, membership of a particular social group or political opinion.

The non-refoulement obligation of the Refugee Convention is complemented by non-refoulement obligations in general international human rights treaties — such as the ICCPR, 151 and the Convention against Torture and Other Cruel, Inhuman or Degrading Treatment or Punishment, ${ }^{152}$ and regional human rights instruments - such as the ECHR, ${ }^{153}$ the $A C H R,{ }^{154}$ the $A H R D,{ }^{155}$ and the ACHPR. ${ }^{156}$ The principle of

non-refoulement. For a discussion of the nature of UDHR art 14, see Gregor Noll, Negotiating Asylum: The EU Aquis, Extraterritorial Protection and the Common Market of Deflection (Martinus Nijhoff Publishers, 2000) 357-62; See also Mark Pallis, 'Obligations of States towards Asylum Seekers at Sea: Interactions and Conflicts between Legal Regimes' (2002) 14 International Journal of Refugee Law 329, 345-6.

150 UNHCR, Note on the Principle of Non-Refoulement (November 1997).

151 See, eg, ICCPR art 7 which states that, '[n]o one shall be subjected to torture or to cruel, inhuman or degrading treatment or punishment. In particular, no one shall be subjected without his free consent to medical or scientific experimentation'.

152 Convention against Torture and Other Cruel, Inhuman or Degrading Treatment or Punishment, opened for signature 10 December 1984, 1465 UNTS 112 (entered into force 26 June 1987) art 3(1) ('CAT') states: 'No State Party shall expel, return ("refouler”) or extradite a person to another State where there are substantial grounds for believing that he would be in danger of being subjected to torture'.

153 ECHR art 3 states: 'No one shall be subjected to torture or to inhuman or degrading treatment or punishment'.

154 ACHR art 22(8) states: 'In no case may an alien be deported or returned to a country, regardless of whether or not it is his country of origin, if in that country his right to life or personal freedom is in danger of being violated because of his race, nationality, religion, social status, or political opinions'.

155 AHRD art 14 states: 'No person shall be subject to torture or to cruel, inhuman or degrading treatment or punishment'. Arguably, this is an expression of the principle of nonrefoulement in the same way as ICCPR art 7.

156 ACHPR art 5 states: 'Every individual shall have the right to the respect of the dignity inherent in a human being and to the recognition of his legal status. All forms of exploitation and degradation of man, particularly slavery, slave trade, torture, cruel, inhuman or degrading punishment and treatment shall be prohibited'. Arguably, this article includes the principle of non-refoulement in the same way as ICCPR art 7. 
non-refoulement is generally held to reflect customary international law. ${ }^{157}$ It follows, from the definition of a 'refugee', ${ }^{158}$ that the non-refoulement obligation is restricted ratione personae so that a person must be outside his or her country of nationality to invoke international protection as a refugee. ${ }^{159}$ However, in order to ensure the effectiveness of the non-refoulement obligation, it needs to be applied also to those who have not formally been recognised as refugees and to those with a presumptive or prima facie claim to refugee status, that is, asylum-seekers. ${ }^{160}$

It is undisputed that the non-refoulement obligation applies within the territory of a state. What has been the subject of a more complicated debate is how it applies extraterritorially, that is, in areas outside the territory of any state. An important event in this debate was in Chris Sale, Acting Commissioner, Immigration and Naturalization Service, et al., Petitioners v Haitian Centres Council, INC., et al where the Supreme Court of the United States of America found that the non-refoulement provision in the Refugee Convention did not apply extraterritorially. ${ }^{161}$ The judgment has been heavily criticised and the better view appears to be that the non-refoulement obligation has extraterritorial effects. ${ }^{162}$ The most influential and, arguably, clearest explanation of the

157 The UNHCR has argued that the principle of non-refoulement is progressively acquiring the character of jus cogens. See, eg, UNHCR, Advisory Opinion on the Extraterritorial Application of Non-Refoulement Obligations under the 1951 Convention relating to the Status of Refugees and its 1967 Protocol (26 January 2007) [15] ('UNHCR Advisory Opinion on the Extraterritorial Application of Non-Refoulement Obligations'); UNHCR, Executive Committee, No. 25 (XXXIII) General, 33 ${ }^{\text {rd }}$ sess (20 October 1982) [(b)]. See also G S Goodwin-Gill and J McAdam, The Refugee in International Law (Oxford University Press, $3^{\text {rd }}$ ed, 2007) 248.

158 Refugee Convention art 1(A)(2) defines a refugee as 'any person who owing to a wellfounded fear of being persecuted for reasons of race, religion, nationality, membership of a particular social group or political opinion, is outside the country of [their] nationality and is unable, or owing to such fear, is unwilling to avail himself [or herself] of the protection of that country' (emphasis added).

159 See Regina (European Roma Rights Centre and Others) v Immigration Officer at Prague Airport and Another (United Nations High Commissioner for Refugees Intervening) [2004] UKHL 55. See also J C Hathaway, The Rights of Refugees under International Law (Cambridge University Press, 2005) 308-9.

160 See, eg, UNHCR, Executive Committee, No. 6 (XXVIII) Non-Refoulement, $28^{\text {th }}$ sess (12 October 1977) [(c)]; UNHCR, Executive Committee, No. 79 (XLVII) General, $4^{\text {th }}$ sess (11 October 1996) [(j)]; UNHCR, Executive Committee, No. 81 (XLVII) General, $48^{\text {th }}$ sess (17 October 1997) [(i)]; UNHCR, Executive Committee, No. 82 (XLVIII) Safeguarding Asylum, 48 ${ }^{\text {th }}$ sess (17 October 1997) [(d)(i)].

161509 US 155 (1993).

162 See, eg, Inter-American Commission on Human Rights, Decision of the Commission as to the Merits of Case 10.675, Report No 51/96 (1997); Regina (European Roma Rights Centre and Others) v Immigration Officer at Prague Airport and Another (United Nations High 
geographical scope of the non-refoulement obligation is found in the UNHCR Advisory Opinion on the Extraterritorial Application of Non-Refoulement Obligations. ${ }^{163}$ The UNHCR argues that the extraterritorial character of the non-refoulement obligation follows from an interpretation of art 33(1) of the Refugee Convention in good faith in accordance with the ordinary meaning to be given to the terms of the treaty, in their context and in the light of the treaty's object and purpose. ${ }^{164}$ The most influential interpretative elements in this opinion appear to be subsequent state practice, and systemic integration. ${ }^{165}$ The material taken into account as subsequent state practice includes a number of Conclusions of the Executive Committee of the UNHCR ('EXCOM Conclusions') and other international refugee and human rights instruments drawn up since 1951. ${ }^{166}$ Bearing in mind that not all parties to the Refugee Convention are members of the Executive Committee of the UNHCR, ${ }^{167}$ and that EXCOM

Commissioner for Refugees intervening) [2004] QB 811 [34]; UNHCR Advisory Opinion on the Extraterritorial Application of Non-Refoulement Obligations 12 [24] n 54.

163 See, eg, UNHCR, 'Seeking Leave to Intervene as Amicus Curiae', Submission in CPCF v Minister for Immigration and Border Protection (2015) 89 ALJR 207, S169/2014, 15 September 2014; See also UNHCR, 'Submission by the Office of the United Nations High Commissioner for Refugees in the Case of Hirsi and Others v. Italy (Application no. 27765/09)', Submission in Case of Hirsi Jamaa and Others v Italy (Judgment) (2012) II Eur Court HR, 27765/09, 29 March 2011, 10-4.

164 Refugee Convention art 33(1) states a simple prohibition, without expressing any territorial limitation: 'No Contracting State shall expel or return ('refouler') a refugee in any manner whatsoever to the frontiers of territories where his [or her] life or freedom would be threatened'. The terms 'in any manner whatsoever' indicates an extensive applicability. Furthermore, there is nothing in the ordinary meaning of the terms 'return' and 'refouler' that indicates a territorial limitation. While several obligations of the Refugee Convention appear to be defined with respect to territory, there is nothing in the terms of art 33(1) that suggests a territorially limited applicability. See, Refugee Convention arts 14-19, 23-8, 312; See also Barnes, above n 3, 67 n 108.

165 UNHCR Advisory Opinion on the Extraterritorial Application of Non-Refoulement Obligations 16-19.

166 Ibid 15 [33]. The actual practice of states in undertaking interception operations at sea is, however, not taken into account. Guilfoyle has argued that the practice of Australia and the US, coupled with other parties' acquiescence, may establish 'an agreement of the parties' that such acts are compatible with the Refugee Convention. However, given the relatively clear meaning of the non-refoulement obligation under the Refugee Convention and the recent practice of European states, this appears as a difficult argument to make: Douglas Guilfoyle, Shipping Interdiction and the Law of the Sea (Cambridge University Press, 2009) 224-6. For a description of the relevant practice within the European Union ('EU'), see below Part II(d).

167 As of August 2015, the Refugee Convention had 145 parties: United Nations, Chapter V Refugees and Stateless Persons (29 February 2016) United Nations Treaty Collection $<$ https://treaties.un.org/Pages/ViewDetailsII.aspx?src=TREATY\&mtdsg_no=V-

2\&chapter=5\&Temp=mtdsg2\&lang=en $>$. The Executive Committee of the UNHCR had 98 
Conclusions are thus not adopted with the support of all parties to the Refugee Convention, it is doubtful whether EXCOM Conclusions may be used as subsequent practice within the meaning of art 31(3)(b) of the VCLT for the interpretation of the non-refoulement obligation. ${ }^{168}$

However, the most influential element of the interpretation is systemic integration. According to the UNHCR, customary international human rights law indicates that the object and purpose includes extraterritorial effects of the non-refoulement obligation. ${ }^{169}$ The basis of the argument is an analysis of numerous international human rights treaties, including the ICCPR, ${ }^{170}$ the $C A T,{ }^{171}$ and the ECHR. ${ }^{172}$ In assessing this argument, it is difficult not to agree with the UNHCR in that the 'the reasoning adopted by courts and human rights treaty bodies in their authoritative

members: UNHCR, ExCom Members and How to Apply (29 February 2016) UNHCR The UN Refugee Agency <http://www.unhcr.org/pages/49c3646c89.html>.

168 It may be recalled that 'parties' shall be read as 'all parties' in VCLT art 31: See Whaling in the Antarctic (Australia v Japan) (Judgment) [2014] ICJ Rep 226, 257 [83] in which the ICJ found that certain resolutions of the International Whaling Commission could not be regarded as subsequent agreement or subsequent practice, within the meaning of the VCLT arts 31(3)(a)-(b), for the interpretation of the International Convention for the Regulation of Whaling, opened for signature 2 December 1946, 161 UNTS 3 (entered into force 10 November 1948), since the resolutions had been adopted without the support of all parties: See also above $\mathrm{n} 78$.

169 UNHCR Advisory Opinion on the Extraterritorial Application of Non-Refoulement Obligations 15-19.

170 The ICCPR has been interpreted to require states 'to respect and to ensure the Covenant rights to all persons who may be within their territory and to all persons subject to their jurisdiction [so] that a State party must respect and ensure the rights laid down in the Covenant to anyone within the power or effective control of that State Party, even if not situated within the territory of the State Party'. See, eg, Human Rights Committee, General Comment No. 31: The Nature of the General Legal Obligation Imposed on States Parties to the Covenant, 80 ${ }^{\text {th }}$ sess, UN Doc CCPR/C/21/Rev.1/Add.13 (20 May 2004, adopted 29 March 2004). See also UNHCR Advisory Opinion on the Extraterritorial Application of Non-Refoulement Obligations 16-17 [36]-[37] and further references there.

171 The Committee against Torture has taken the view that the CAT applies in any territory under the jurisdiction of a state party. UNHCR Advisory Opinion on the Extraterritorial Application of Non-Refoulement Obligations 17 [38] and further references there.

172 The European Court of Human Rights has consistently held that the decisive criterion is not whether a person is within the territory of the state concerned, but of, or is affected by those acting on behalf of, the state in question. Ibid 17-18 [39]-[40] and further references there. See also Hirsi Jamaa, in which the European Court of Human Rights found that Italy had violated certain obligations under the ECHR, including the non-refoulement obligation under ECHR art 3 (prohibition of torture), by returning a group of Somali and Eritrean migrants to Libya after having intercepted them in international waters off the Italian coast. Hirsi Jamaa and Others v Italy (Judgment) (2012) ECHR 2012-II (European Court of Human Rights). 
interpretation of the relevant human rights provisions is relevant also to the prohibition of refoulement under international refugee law, given the similar nature of the obligations and the object and purpose of the treaties which form their legal basis'. ${ }^{173}$ The requirement that only relevant rules may be taken into account through systemic integration is thus met. The requirement that only applicable rules may be taken into account is met by the customary nature of the relevant international human rights law. ${ }^{174}$

A more difficult question is whether customary international human rights law can be said to consistently apply extraterritorially. ${ }^{175}$ However, the rule to be taken into account in the interpretation of the non-refoulement obligation in the Refugee Convention is the geographical scope of the non-refoulement obligations in customary international human rights law - not human rights treaty law in general. At least the $I C C P R$ and the CAT reflect these customary rules. Arguably, these rules provide a sufficiently consistent meaning so that they can be taken into account through systemic integration as an indication of extraterritorial applicability of the non-refoulement obligation of the Refugee Convention. ${ }^{176}$ Hence, there are convincing reasons to understand the non-refoulement obligation of the Refugee Convention to apply wherever a person is subject to the jurisdiction of a state. ${ }^{177}$

It may seem that questions of the extraterritorial effect of the non-refoulement obligation is of somewhat subordinate nature as regards the interdiction of migrants at sea, since interdiction at sea does not always entail returning persons to a territory or even to the frontiers of a territory, but may involve no more than pushing them back into international waters. In such situations, it may seem more relevant to consider if the non-refoulement obligation entails an obligation to determine the status of asylum-

173 UNHCR Advisory Opinion on the Extraterritorial Application of Non-Refoulement Obligations 19 [42].

174 See above $n 79$

175 Noll, 'Seeking Asylum at Embassies', above n 79.

176 CAT art 2(1) provides: 'Each State Party shall take effective legislative, administrative, judicial or other measures to prevent acts of torture in any territory under its jurisdiction'. Similarly, ICCPR art 2(1) provides: 'Each State Party to the present Covenant undertakes to respect and to ensure to all individuals within its territory and subject to its jurisdiction the rights recognized in the present Covenant'. Furthermore, the ICJ has held that 'the [ICCPR] is applicable in respect of acts done by a State in the exercise of its jurisdiction outside its own territory': Legal Consequences of the Construction of a Wall in the Occupied Palestinian Territory (Advisory Opinion) (2004) ICJ Rep 136, 48 [111].

177 This is also the position generally supported in doctrine. See, eg, Hathaway, above n 159, 335-42; Den Heijer, 'Europe beyond its Borders: Refugee and Human Rights Protection in Extraterritorial Immigration Control' in Bernard Ryan and Valsamis Mitsilegas (eds), Extraterritorial Immigration Control: Legal Challenges (Martinus Nijhoff Publishers, 2010) 169, 181-8; UNHCR Advisory Opinion on the Extraterritorial Application of NonRefoulement Obligations; Pallis, above n 149, 344-5. For a more tentative approach, see Noll, ‘Seeking Asylum at Embassies', above n 79. 
seekers ('screening') before such pushbacks take place. Although it is well-settled that a person is a refugee because he or she is outside their country, having fled due to a well-founded fear of persecution - rather than the assessment and declarations of any state - there appears to be increasing support for the existence of a norm of refugee status determination under international law. ${ }^{178}$

The core of such a norm derives from the non-refoulement obligation. Logically, since the non-refoulement obligation prohibits a state from returning refugees and the only way to determine who is a refugee is through refugee status determination, such a determination being necessary in order to ensure the effectiveness of the nonrefoulement obligation. ${ }^{179}$ Consequently, an obligation to determine refugee status may exist in situations when the return of the asylum-seekers would leave them with no alternative but to return home (de facto refoulement) or to a third country from where they would be sent back home (chain refoulement), 'as opposed to mere rejection at a frontier where options to travel elsewhere exist'. 180 Accordingly, this leaves legal room for a state not to determine the status of an asylum-seeker if it can be ascertained that returning him or her to a third country or other rejection would not result in any form of refoulement. An important question in this regard - but one which goes beyond the limits of this article - is how and under what conditions such initial screening may be conducted.

The last issue for consideration is the prohibition on imposing penalties on refugees on account of their illegal entry or presence. ${ }^{181}$ The basic meaning of the prohibition which represents a corollary of the fundamental right to leave any country ${ }^{182}$ — is that as long as refugees' failure to present the necessary travel documents or contravention

178 Barnes, above n 58, 116, citing Pallis, above n 146, 345.

179 Pallis, above $n$ 146, 346-7.

180 Barnes, above n 58, 116-17.

181 Refugee Convention art 31(1) provides: 'The Contracting States shall not impose penalties, on account of their illegal entry or presence, on refugees who, coming directly from a territory where their life or freedom was threatened in the sense of article 1, enter or are present in their territory without authorization, provided they present themselves without delay to the authorities and show good cause for their illegal entry or presence'.

182 The right to leave any country, including one's own, is set out in, inter alia, UDHR art 13(2) and ICCPR art 12(2). For a comprehensive discussion of Refugee Convention art 31, see Guy S Goodwin-Gill, 'Article 31 of the 1951 Convention Relating to the Status of Refugees: Non-Penalization, Detention, and Protection' in Erika Feller, Türk Volker and Frances Nicholson (eds), Refugee Protection in International Law: UNHCR's Global Consultations on International Protection (Cambridge University Press, 2003). See also Andreas Schloenhardt and Hadley Hickson, 'Non-Criminalization of Smuggled Migrants: Rights, Obligations, and Australian Practice under Article 5 of the Protocol Against the Smuggling of Migrants by Land, Sea, and Air' (2013) 25(1) International Journal of Refugee Law 39, 45. 
of applicable immigration laws is incidental to their flight from the risk of persecution, they should not be penalised on account of their illegal entry. ${ }^{183}$ The prohibition speaks only of refugees, but it applies also to presumptive refugees, that is, asylum-seekers. ${ }^{184}$ A central question in relation to the scope of the prohibition is whether the term 'penalty' shall be interpreted restrictively or expansively, so that it includes not only traditional penalties (such as imprisonment) but also administrative sanctions (such as immigration detention and restricted procedural rights in the refugee status determination process). An important argument for the latter interpretation is that the Human Rights Committee has embraced an extensive interpretation of the term 'penalty' in art 15 of the ICCPR (prohibition of ex post facto criminality). ${ }^{185}$ As regards interdiction or rescue of migrants at sea it must be noted that the prohibition on imposing penalties applies to 'refugees ... who enter or are present in ... territory without authorization'. ${ }^{186}$

Naturally, it is not only occasionally that refugees and other migrants are intercepted or rescued in international waters without, or before, having entered any state's territory. In such cases, the prohibition on imposing penalties cannot be applicable since it is conditioned on physical presence in the territory of a state. However, if interception or rescue takes place in the territorial sea or within the internal waters of a state, the prohibition applies. The obligation not to impose sanctions amounting to 'penalties' on account of a refugee being within the territory of a state may indeed be relevant in relation to the concept of place of safety. For example, it may not be justified to disembark rescued refugees and asylum-seekers at a location where they will be subject to imprisonment on account of their illegal entry.

Nonetheless, these rules may not be taken into account in the interpretation of the concept of place of safety. The reason is that these rules do not apply to all the parties to the SOLAS and SAR Conventions. Moreover, not all parties to those conventions are parties to the Refugee Convention, and it is not likely that these rules have attained

183 Hathaway means that 'there is no sound basis to interpret the notion of "penalty" narrowly'. Hathaway, above n 159, 406. See also Goodwin-Gill and McAdam, above n 157, 266.

184 Refugee Convention art 31(1) speaks only of 'refugees', but since it cannot be known if a person is a refugee before his or her status has been determined, the same needs to be applied in relation to those with a prima facie claim to refugee status (ie asylum-seekers). See also Hathaway, above n 159, 389; Goodwin-Gill, above n 182, 193, 219.

185 Arguably, the prohibition of ex post facto criminality reflects a customary rule which is both relevant and applicable in relation to the interpretation of the prohibition to impose penalties on refugees under the Refugee Convention: Hathaway, above n 159, 411-12.

186 Refugee Convention art 31(1). 
customary status. ${ }^{187}$ As result, the prohibition on imposing penalties under art 31 of the Refugee Convention may not be taken into account in the interpretation.

International refugee law ties into the interpretation of the concept of place of safety through the customary non-refoulement obligation. Given the general and open-ended character of the concept of place of safety, it can be assumed that the parties' common intention upon conclusion of the 2004 amendments to the SOLAS and SAR Conventions was to give the concept a meaning that reflects obligations enshrined in other relevant and applicable rules of international law. What has been argued above is that the customary non-refoulement obligation is an integral aspect of the concept of place of safety and thus the disembarkation rules. This interpretation is supported by references to non-refoulement in the IMO Guidelines on the Treatment of Persons Rescued at Sea:

The need to avoid disembarkation in territories where the lives and freedoms of those alleging a well- founded fear of persecution would be threatened is a consideration in the case of asylum-seekers and refugees recovered at sea. ${ }^{188}$

The Refugee Convention's prohibition of expulsion or return ('refouler') contained in art 33(1) prohibits Contracting States from expelling or returning a refugee to the frontiers of territories where his or her life or freedom would be threatened on account of the person's race, religion, nationality, membership of a particular social group or political opinion. Other relevant international law also contains prohibition on return to a place where there are substantial grounds for believing that the person would be in danger of being subjected to torture. ${ }^{189}$

\section{(iii) International law against transnational organised crime}

The United Nations Convention against Transnational Organized Crime is the principal legal instrument in the fight against transnational organised crime. ${ }^{190}$ It is supplemented by three protocols focusing on different areas of transnational organised crime (trafficking of persons, smuggling of migrants, and illicit manufacturing of and trafficking of firearms). For the purposes of this article, the Protocol against the Smuggling of Migrants by Land, Sea and Air, supplementing the United Nations Convention against Transnational Organized Crime is of principal interest. ${ }^{191}$

187 See, eg, Goodwin-Gill, above n 182, 206-8 who refers to two comprehensive studies showing wide variations in state practice.

188 IMO Guidelines, IMO Doc MSC 78/26/Add.2 annex 34, annex para 6.17.

189 Ibid appendix ('Some Comments on Relevant International Law') [7].

190 United Nations Convention against Transnational Organized Crime, opened for signature 15 Novermber 2000, 2225 UNTS 209 (entered into force 29 September 2003).

191 Protocol against the Smuggling of Migrants by Land, Sea and Air, supplementing the United Nations Convention against Transnational Organized Crime, opened for signatue 15 November 2000, 2241 UNTS 507 (entered into force 28 January 2004) ('Smuggling of Migrants Protocol'). Whereas smuggling of migrants involves the procurement of illegal 
The purpose of the Smuggling of Migrants Protocol is threefold: 'to prevent and combat the smuggling of migrants, as well as to promote cooperation among States Parties to that end, while protecting the rights of smuggled migrants'. ${ }^{192}$ The definition of smuggling of migrants is of central importance. It reads:

"Smuggling of Migrants" shall mean the procurement, in order to obtain, directly or indirectly, a financial or other material benefit, of the illegal entry of a person into a State Party of which the person is not a national or a permanent resident. ${ }^{193}$

Starting with the objective to prevent and combat the smuggling of migrants, art 6(1) of the Smuggling of Migrants Protocol requires States Parties to adopt legislative and other measures to criminalise the smuggling of migrants, handling fraudulent travel or identity documents and enabling a person to remain in a state by illegal means. The protocol does not explicitly oblige States Parties to investigate and prosecute persons suspected of smuggling of migrants. However, such an obligation exists under the protocol as an implicit feature of criminalisation ('legislative and other measures as may be necessary to establish as criminal offences'). ${ }^{194}$ The protocol also requires States Parties to cooperate to prevent and suppress the smuggling of migrants at sea, and provides for certain measures that may be taken to this end. ${ }^{195}$ For the objective to protect the rights of migrants, art 5 of the protocol provides, '[m]igrants shall not become liable to criminal prosecution under this Protocol for having been the object of [smuggling of migrants]'. Moreover, art 16(1) requires States Parties to take 'all appropriate measures ... to preserve and protect the rights of persons who have been the

entry of a person into a country for material benefit, trafficking of persons involves threat or use of force or other forms of coercion for the purpose of exploitation. The Protocol to Prevent, Suppress and Punish Trafficking in Persons, Especially Women and Children, supplementing the United Nations Convention against Transnational Organized Crime, opened for signature 15 November 2000, 2237 UNTS 319 (entered into force 25 December 2003) art 3(a) defines trafficking of persons as 'the recruitment, transportation, transfer, harbouring or receipt of persons, by means of the threat or use of force or other forms of coercion, of abduction, of fraud, of deception, of the abuse of power or of a position of vulnerability or of the giving or receiving of payments or benefits to achieve the consent of a person having control over another person, for the purpose of exploitation'. Although the boundaries between smuggling of migrants and trafficking of persons are far from clearcut, it is a fact that most migrants being transported at sea for illegal entry into a state are not transported for the purpose of exploitation - at least not within the meaning of the definition of trafficking of persons. For further discussion on this distinction, see Patricia Mallia, Migrant Smuggling by Sea: Combating a Current Threat to Maritime Security through the Creation of a Cooperative Framework (Martinus Nijhoff Publishers, 2010) 911.

192 Smuggling of Migrants Protocol art 2.

193 Ibid art 3(a).

194 The obligation to interpret a treaty in good faith and the principle of effective interpretation may be recalled in this regard: VCLT art 31(1).

195 Smuggling of Migrants Protocol arts 7-8. 
object of [smuggling of migrants] as accorded under applicable international law, in particular the right to life and the right not to be subjected to torture or other cruel, inhuman or degrading treatment or punishment'. Furthermore, States Parties are obliged to afford migrants 'appropriate protection against violence that may be inflicted upon them ... by reason of being the object of [smuggling of migrants]' as well as 'appropriate assistance to [those] whose lives or safety is endangered by reason of being the object of [smuggling of migrants]'. ${ }^{196}$

Two features of the Smuggling of Migrants Protocol are of particular interest in the context of this article: the obligation to criminalise the smuggling of migrants, and the obligation to preserve and protect the rights of smuggled migrants. Both matters are relevant to situations where migrants have been rescued at sea. First, persons rescued at sea that may be suspected of having engaged in the smuggling of migrants shall be disembarked and delivered to a place of safety where further investigation measures can be taken. Second, a smuggled migrant who has been rescued at sea is also entitled to disembarkation at a place of safety, pursuant to the disembarkation rules under the SOLAS and SAR Conventions, but, pursuant to art 5 of the Smuggling of Migrants Protocol, is not to be liable to criminal prosecution for the fact of having been the object of smuggling. Hence, it may not be lawful for States Parties to the Smuggling of Migrants Protocol to disembark smuggled migrants rescued at sea at a place of safety where the likely treatment of the migrants will in practice amount to a 'penalty', for example at a place where the rescued persons are held in indefinite confinement equal to imprisonment. ${ }^{197}$ Moreover, the protocol entitles smuggled migrants to protection from violence that may be inflicted upon them by reason of being smuggled migrants, and to assistance when their lives or safety are endangered by reason of their status as smuggled migrants. States Parties to the protocol must thus not disembark smuggled migrants rescued at sea at a place of safety where their lives or safety would be endangered by reason of being smuggled migrants.

Although the rules on non-criminalisation and protection of victims of migrant smuggling may be relevant in situations when migrants are to be disembarked following rescue at sea, it is not likely that they are also applicable so that they may be taken into account through systemic integration in the interpretation of the disembarkation rules. The reason is that the Smuggling of Migrants Protocol does not apply to all the parties to the disembarkation rules. ${ }^{198}$ It is not likely that these rules

196 Ibid arts 16(2)-(3).

197 For further discussion on the relation between non-criminalisation and detention of migrants, see Schloenhardt and Hickson, above n 182.

198 For example Bangladesh, China, Colombia, Iran, Jordan, Singapore, Thailand, United Arab Emirates and Vietnam were in February 2015 bound by the concept of place of safety (as provided by either the SOLAS Convention or the SAR Convention), but had not ratified the Smuggling of Migrants Protocol. Cf International Maritime Organization, above n 50; 
have attained customary status. Consequently, the rules found in the Smuggling of Migrants Protocol may not be used for the interpretation of the concept of place of safety, at least not through a primary means of interpretation. ${ }^{199}$ However, this does not mean that these rules cease to apply for States Parties to the protocol during a rescue and disembarkation operation. Acts by States Parties may thus amount to independent violations of their treaty obligations under the protocol, even if those acts were conducted during a rescue and disembarkation operation within the scope of the international disembarkation rules which may impose a lesser level of obligation.

\section{(d) Supplementary means of interpretation}

Article 32 of the VCLT provides that recourse may be had to supplementary means of interpretation in order to confirm the meaning of a treaty resulting from the use of primary means of interpretation, or to determine the meaning if the use of primary means of interpretation leaves the meaning ambiguous or obscure, or leads to a result which is manifestly absurd or unreasonable. As is evident from the discussion above, the phrase 'place of safety' is a fairly detailed concept when interpreted in the wider context of international law. Supplementary means of interpretation may thus not be used to determine the meaning. Instead, recourse may be had to supplementary means of interpretation in order to confirm the meaning resulting from the application of the general rule of interpretation.

The international disembarkation rules were adopted following lengthy negotiations and careful preparation within the IMO. The negotiation records show that the rules were prepared, drafted and adopted with a focus on situations when migrants are rescued at sea, such as the Tampa affair. ${ }^{200}$ Importantly, the travaux préparatoires confirm that the phrase 'place of safety' was meant as a broad concept encompassing not only interests fixed in maritime law, ${ }^{201}$ but also aspects of general international

United Nations Office of Legal Affairs, Multilateral Treaties Deposited with the SecretaryGeneral Database, Chapter XVIII <https://treaties.un.org/>.

199 This does not preclude their use as a supplementary means of interpretation. See Linderfalk, above n 71, 259-65.

200 This was explicitly noted by Norway during the negotiations: Decisions of Other IMO Bodies: Review of Safety Measures and Procedures for the Treatment of Persons Rescued at Sea (Submitted by Norway), MSC, $75^{\text {th }}$ sess, Agenda Item 2, IMO Doc MSC 75/2/2/Add.2 (12 March 2002) 3 [6].

201 See, eg, Review of Safety Measures and Procedures for the Treatment of Persons Rescued at Sea, Assembly, 22 ${ }^{\text {nd }}$ sess, Agenda Item 8, IMO Doc A 22/Res.920 (22 January 2002) in which the Assembly of the IMO requests a revision of certain conventions so that 'survivors of distress incidents are given assistance regardless of nationality or status or the circumstances in which they are found; ships which have retrieved persons in distress at sea are able to deliver the survivors to a place of safety; and survivors, regardless of nationality or status, including undocumented migrants, asylum-seekers, refugees and stowaways are treated while on board in the manner prescribed in the relevant IMO instruments and in 
law, such as the right of a state to control immigration to its territory, ${ }^{202}$ and of international refugee law in particular, such as the non-refoulement obligation. ${ }^{203}$ The travaux also make it clear that the disembarkation rules do not establish a right for the shipmaster to decide where persons rescued at sea shall be disembarked, but only obligations of states to ensure that a place of safety is provided. ${ }^{204}$ In sum, the travaux confirm that the phrase 'place of safety' was intended to be a broad concept, in line with the interpretation presented above.

Another type of supplementary means of interpretation relevant to the present interpretation is agreements on the same subject matter (in pari materia) among a subgroup of parties to the interpreted treaty. Such agreements do not fit within arts 31(3)(a)-(b) of the VCLT, as they do not bind all parties to the treaty, and may not be used as a primary means of interpretation. ${ }^{205}$ However, they may be used as supplementary means of interpretation. ${ }^{206}$ An important such supplementary means as

accordance with relevant international agreements and long-standing humanitarian maritime traditions' (emphasis added). See also Report to the Maritime Safety Committee, Sub-Committee on Radiocommunications and Search and Rescue, $7^{\text {th }}$ sess, Agenda Item 22, IMO Doc COMSAR 7/23 (20 February 2003) 27-8 [8.10]-[8.13].

202 See, eg, Report to the Maritime Safety Committee, Sub-Committee on Radiocommunications and Search and Rescue, $7^{\text {th }}$ sess, Agenda Item 22, IMO Doc COMSAR 7/23 (20 February 2003) [8.29] in which the United States emphasises 'the interests of the State to protect its borders and other sovereignty concerns'; Report to the Maritime Safety Committee, Sub-Committee on Radiocommunications and Search and Rescue, $6^{\text {th }}$ sess, Agenda Item 22, IMO Doc COMSAR 6/22 (8 March 2002) 36 [8.65] where Australia, supported by the United States, 'opposed any proposals for amendments ... which would have the effect of extending convention obligations to encompass disembarkation of rescued persons at a particular port...'. This interest is also reflected in the appendix to the IMO Guidelines, IMO Doc MSC 78/26/Add.2 annex 34: 'As a general principle of international law, a State's sovereignty allows that State to control its borders, to exclude aliens from its territory and to prescribe laws governing the entry of aliens into its territory'.

203 See, eg, Report to the Maritime Safety Committee, Sub-Committee on Radiocommunications and Search and Rescue, $7^{\text {th }}$ sess, Agenda Item 22, IMO Doc COMSAR 7/23 (20 February 2003) 28 [8.13] where the UNHCR emphasises the nonrefoulement obligation

204 See, eg, Report of the Maritime Safety Committee on its Seventy-Eight Session, MSC, 78 ${ }^{\text {th }}$ sess, Agenda Item 26, IMO Doc MSC 78/26 (28 May 2004) 21 [3.41]; Consideration and Adoption of Amendments to Mandatory Instruments: Amendments to the 1979 SAR Convention (Submitted by Spain), MSC, $78^{\text {th }}$ session, Agenda Item 3, IMO Doc MSC 78/3/7 (12 December 2003); Report to the Maritime Safety Committee, Sub-Committee on Radiocommunications and Search and Rescue, $6^{\text {th }}$ sess, Agenda Item 22, IMO Doc COMSAR 6/22 (8 March 2002) 36 [8.65].

205 Reference may be made to the discussion in the EC-Biotech case, above n 78.

206 Villiger, above n 74, 446; Aust, above n 68, 220; Linderfalk, above n 68, 255-9. The reason for why agreements in pari materia among a sub-group of parties can be used as 
regards the concept of place of safety is the EU rules on disembarkation of persons rescued at sea during sea border operations. These rules are found in Regulation (EU) No 656/2014 of the European Parliament and of the Council of 15 May 2014 Establishing Rules for the Surveillance of the External Sea Borders in the Context of Operational Cooperation Coordinated by the European Agency for the Management of Operational Cooperation at the External Borders of the Member States of the European Union. ${ }^{207}$ The regulation applies to border surveillance operations carried out by member states of the EU at their external sea borders in the context of operational cooperation coordinated by the European Agency for the Management of Operational Cooperation at the External Borders of the Member States of the EU ('FRONTEX'). 208 The regulation includes provisions on, inter alia, detection, interception, search and rescue situations and disembarkation. The regulation also includes substantial provisions on protection of fundamental rights and the principle of non-refoulement. Importantly, the regulation incorporates protection of fundamental rights and the principle of non-refoulement in its definition of 'place of safety'. ${ }^{209}$ The regulation confirms in this way an extensive meaning of the concept of place of safety, in line with the interpretation presented above. ${ }^{210}$

Lastly, techniques for resolving normative conflicts, such as lex posterior derogat legi priori ${ }^{211}$ and lex specialis derogat legi generali, ${ }^{212}$ may be used as supplementary means of interpretation. ${ }^{213}$ Naturally, such techniques may be used only if there is a

supplementary means of interpretation is basically the same as for why the elements referred to in art 31(3) of the VCLT can be used as primary means of interpretation: no treaty exists and operates isolated from its normative environment. In the same way as other relevant and applicable rules of international law are indicative of the intentions of the parties, and shall be used as a primary means of interpretation under VCLT art 31(3)(c), other relevant and semi-applicable rules of international law can be indicative of the intentions of the parties, and may be used as a supplementary means of interpretation.

Regulation (EU) No 656/2014 of the European Parliament and of the Council of 15 May 2014 Establishing Rules for the Surveillance of the External Sea Borders in the Context of Operational Cooperation Coordinated by the European Agency for the Management of Operational Cooperation at the External Borders of the Member States of the European Union [2014] OJ L 189/93.

208 Ibid art 1.

209 Ibid arts 2(12), 4, 10.

210 For further description and analysis of the practice within the EU, see, eg, European Union Agency for Fundamental Rights, Fundamental Rights at Europe's Southern Sea Borders (2013) <https://fra.europa.eu/sites/default/files/fundamental-rights-europes-southern-seaborders-jul-13_en.pdf $>$.

211 When two rules apply to the same matter, the later in time prevails.

212 A specific rule prevails over a general rule.

213 Aust, above n 71, 220-1; Villiger, above n 74, 445-6. See also Linderfalk, above n 71, 311-12. 
normative conflict within the interpretation. There is no such conflict as regards the concept of place of safety. The various relevant and applicable norms taken into account in the interpretation do not give rise to any normative conflict within the interpretation. ${ }^{214}$

\section{(e) Summary}

The primary sources for interpretation of the concept of place of safety in the SOLAS and SAR Conventions are the text, the context and the object and purpose of the treaties. It follows from the ordinary meaning of the terms that a 'place of safety' is a geographical location where persons rescued at sea are protected from danger, risk, or injury. Determining whether a particular location is a 'place of safety' must necessarily account for the particular circumstances of the case (such as the situation on board the assisting ship, on scene conditions, medical needs, and availability of transportation or other rescue units). A place of safety is a location 'where rescue operations are considered to terminate ... [and] where the survivors' safety of life is no longer threatened and where their basic human needs (such as food, shelter and medical needs) can be met'.215 It may be on land or aboard a rescue unit. It is a place that can be reached within a reasonable time so that disembarkation from the assisting ship can be effected as soon as reasonably practicable. It follows from the principle of systemic integration that a place of safety is a location to which the survivors can be delivered without having their fundamental rights violated. Importantly, it is a location where the survivors are not at serious risk of being subject to torture, persecution or other inhuman or degrading treatment or punishment, or where their lives or freedom would be threatened on account of their race, religion, nationality, sexual orientation, membership of a particular social group or political opinion. The identification of a place of safety must also take into account other applicable and relevant rules of international law, including the right to life, the right to family unity and prohibitions of discrimination. Disembarkation that amounts to discrimination, refoulement or any other violations of the survivors' fundamental rights cannot constitute delivery to a place of safety. This interpretation is confirmed by the travaux préparatoires and recent practice of the member states of the EU.

214 This does not preclude that such normative conflicts may arise between two or more rules during a disembarkation operation. However, such conflicts would be outside the interpretation of the concept of place of safety - and are thus beyond the scope of this article.

215 IMO Guidelines, IMO Doc MSC 78/26/Add.2 annex 34, annex para 6.12. 


\section{PART III - ILLUSTRATION: AUSTRALIA}

\section{(a) Overview of applicable legislation}

Australia is a party to the SOLAS and SAR Conventions. ${ }^{216}$ The obligation to render assistance to persons in distress at sea is set out in Australian law by the Navigation Act 2012. ${ }^{217}$ The obligation applies to both foreign and Australian vessels. ${ }^{218}$ It applies to most government vessels, ${ }^{219}$ including Australian customs vessels unless the customs vessel management plan provides otherwise; ${ }^{220}$ warships, naval auxiliary vessels and foreign customs and law enforcement vessels are exempted. ${ }^{221}$ Omission to render assistance at sea is a criminal offence under Australian law. ${ }^{222}$

The Australian Maritime Safety Authority is responsible for providing search and rescue services in a manner consistent with Australia's obligations under the Convention on International Civil Aviation, ${ }^{223}$ and the SOLAS and SAR Conventions. ${ }^{224}$ The Authority shall perform its functions in a manner consistent with the obligations of Australia under any agreement between Australia and another country. ${ }^{225}$ Australia's search and rescue region includes Australian territory and large areas of the Indian, Pacific and Southern Oceans as well as the Australian Antarctic

216 The SOLAS Convention entered into force for Australia on 17 November 1983. The 1978 Protocol to the SOLAS Convention entered into force for Australia on 17 November 1983 , and the 1988 Protocol entered into force generally and for Australia on 3 February 2000. Cf SOLAS Convention art X(b); International Maritime Organization, above n 50. See also International Convention for the Safety of Life at Sea [1983] ATS 22 (entered into force 25 May 1980); Protocol of 1978 relating to the International Convention for Safety of Life at Sea of 1 November 1974 [1983] ATS 28 (entered into force 1 May 1981); Protocol of 1988 relating to the International Convention for the Safety of Life at Sea of 1 November 1974 [2000] ATS 3 (entered into force 3 February 2000).

217 Navigation Act 2012 (Cth) s 181 provides: 'The master of a vessel contravenes this subsection if ... the vessel is at sea; ... the master has reason to believe that one or more persons are in distress at sea; and ... the master does not both ... cause the vessel to proceed as fast as practicable to the assistance of the person or persons; and ... inform the person or persons that the master is doing so'.

218 Ibid s 180

219 Ibid ss 10, 15, 180.

220 Ibid ss 11, 15(2), 180(a).

221 Ibid s 10.

222 Ibid s 181(3).

223 Convention on International Civil Aviation, opened for signature 7 December 1944, 102 UNTS 295 (entered into force 4 April 1947), as amended.

224 Australian Maritime Safety Authority Act 1990 (Cth) ss 6(1), (5).

225 Ibid s 7. 
territories. ${ }^{226}$ It is an area of more than 50 million square kilometres or about $10 \%$ of the surface of the earth. Australia's search and rescue system builds upon cooperation between several authorities and the capacity to use non-designated assets in search and rescue operations. ${ }^{227}$ Joint operating procedures are set out in the National Search and Rescue Manual, which recognises that '[t]he primary purpose of any [search and rescue] action is the speedy return to a place of safety of the survivors of a distress situation'. ${ }^{228}$ However, the National Search and Rescue Manual does not provide for any procedures for the determination of a place of safety - thus leaving this determination to the Rescue Coordination Centre to decide taking into account the circumstances of the case.

The Maritime Powers Act provides 'enforcement powers for use in, and in relation to maritime areas'.229 The powers are exercised by maritime officers, comprising members of, inter alia, the Australian Defence Force and officers of Customs. ${ }^{230}$ The MPA authorizes a maritime officer to detain vessels and the persons on board and take the persons to a place in or outside the migration zone, including a place outside Australia. ${ }^{231}$ The concept of place of safety is reflected in s 74 of the MPA, which provides that a maritime officer 'must not place or keep a person in a place, unless the officer is satisfied, on reasonable grounds, that it is safe for the person to be in that place'. 232

\section{(b) Operation Sovereign Borders}

In September 2013, the Government of Australia announced a new border security campaign aimed at preventing asylum-seekers from entering Australia by boat. Operation Sovereign Borders is a civilian law enforcement operation run as a joint agency taskforce led by a military commander reporting to the Minister for Immigration

226 Maps of the Australian Search and Rescue Region are included in an appendix to the National Search and Rescue Manual, see Australian National Search and Rescue Council, National Search and Rescue Manual 2013 (Australian Maritime Safety Authority, Government of Australia, 2013) <http://natsar.amsa.gov.au/Manuals/index.asp> app A. The National Search and Rescue Manual is promulgated by the National Search and Rescue Council operating under direction from the relevant Commonwealth, State and Territory Ministers. The manual is published by the Australian Maritime Safety Authority on behalf of the National Search and Rescue Council. Ibid 1.

228 Ibid 226 [6.1.1].

229 Australian Maritime Powers Act 2013 (Cth) s 7 ('MPA').

230 MPA s 104.

231 MPA ss 69(1), 72(4).

232 See below Part IV(c). 
and Border Protection. ${ }^{233}$ The background of the operation was an election commitment to 'stop the boats' by instructing the Australian Defence Force to 'turn back boats where it is safe to do so'. ${ }^{234}$ The operation commenced shortly after the federal election in 2013. It was described as 'the Government's response to stopping the flow of illegal boat arrivals to Australia'. ${ }^{235}$

Not much information on operational aspects of Operation Sovereign Borders has been publicly available. ${ }^{236}$ However, numerous media reports indicate that tow-back operations have been conducted. It has been alleged that Australian authorities have used heavy duty 'unsinkable orange lifeboats' for expediting such operations. ${ }^{237}$ The first tow-back operation is believed to have taken place in December 2013, followed by several operations in 2014. It seems that the practice has been to intercept suspected vessels within Australian territorial waters or within its contiguous zone. The asylumseekers have then been towed to a third country, generally Indonesia, on board either the intercepted vessel itself or a lifeboat provided by the Australian authorities. It is thought that tow-back operations have continued far into Indonesia's territorial sea,

233 A cursory description of the operation is available in Senate References Committee, Breaches of Indonesian Territorial Waters (27 March 2014) Parliament of Australia, $<$ http://www.aph.gov.au/Parliamentary_Business/Committees/Senate/Foreign_Affairs_Def ence_and_Trade/Breach_of_Indonesian_Territorial_Waters/Report/index>.

234 The operation was formulated in rather clear terms in policy documents — see Liberal Party of Australia and the Nationals for Regional Australia, above n 9.

235 Minister for Immigration and Border Protection Scott Morrison, 'Press Conference Operation Sovereign Borders Update’ (Speech delivered at Sydney, 23 September 2013).

236 The Minister for Immigration and Border Protection of Australia has repeatedly said that information on on-water activities and certain other operational matters of Operation Sovereign Borders will, as a principle, not be disclosed. See, eg, a letter from the Minister to the Senate References Committee on Breaches of Indonesian Territorial Waters: Senate References Committee, above n 233, app 6.

237 See, eg, George Roberts, Details of Tow-Back under Operation Sovereign Borders Emerge (17 March 2014) ABC News (online) <http://www.abc.net.au/pm/content/2014/s3965086.htm>; Michael Bachelard, Asylum Seekers Say They Were Tricked by Navy (17 January 2014) Sydney Morning Herald (online) <http://www.smh.com.au/federal-politics/political-news/asylum-seekers-say-theywere-tricked-by-navy-20140116-30xtz.html>; Michael Bachelard, Vomitous and Terrifying: the Lifeboats Used to Turn Back Asylum Seekers, (2 March 2014) Sydney Morning Herald (online) <http://www.smh.com.au/national/vomitous-and-terrifying-thelifeboats-used-to-turn-back-asylum-seekers-20140301-33t6s.html>; Paul Toohey, How the Lifeboat Was First Discovered on Shore in West Java, (1 February 2014) News.com.au (online) <http://www.news.com.au/national/how-the-lifeboat-was-first-discovered-onshore-in-west-java/story-fncynjr2-1226815344168>. 
supposedly in order to bring the towed vessel relatively close to the coast before releasing the towline. ${ }^{238}$

Given that many attempts to enter Australia irregularly are undertaken by unsafe means, including overloaded and unseaworthy ships, it is not surprising that distress situations involving migrants at sea occur relatively often within Australia's search and rescue region. ${ }^{239}$ Hence, it is not surprising that there is a close relationship between border control and maritime search and rescue in Australia. A controversial issue in many rescue operations coordinated by Australia is where rescued asylum-seekers should be brought for disembarkation. It appears that the established practice before 2012 was to disembark rescued asylum-seekers on Christmas Island. ${ }^{240}$ However, it seems that this practice has changed. Recent reports indicate that rescued asylumseekers are more likely to be returned to Indonesia or taken to a third country without ever reaching Australian soil. ${ }^{241}$ Although the facts remain unclear, it seems that

238 In early 2014 it was acknowledged that Australian warships engaged in Operation Sovereign Borders had entered into Indonesian territorial waters on several occasions and that Australia had offered 'an unqualified apology' to Indonesia. See, eg, Senate References Committee, above n 233, 1; Minister for Immigration and Border Protection Scott Morrison, 'Operation Sovereign Borders Update' (Speech delivered at Canberra, 17 January 2014). It is thought that the intrusions happened during tow-back operations, but this has not been officially admitted nor denied.

239 It has been estimated that about a third of all suspected irregular entry vessels to Australia in 2010-12 were potentially in distress: Australian Customs and Border Protection Service, 'Maritime Operations and Incidents' (FOI Document, 15 October 2012) <http://www.sievx.com/articles/FOI/Customs/2013/2012-047216_KEYISSUE1FO1Doc2.pdf $>18$.

240 Of ten rescue operations coordinated by the Australian Rescue Coordination Centre in 2009-13 and considered as 'Significant SAR/SOLAS events' by the Australian Customs and Border Protection Service, all but one resulted in disembarkation on Christmas Island. The exception was a rescue in July 2012 by a private ship that resulted in disembarkation in Singapore: ibid 46-71.

241 In late September 2013 it was reported that Australian rescue ships had transferred a group of rescued persons to Indonesian authorities after having assisted in a rescue operation coordinated by Indonesia. The event coincided with the commencement of Operation Sovereign Borders and was reported to indicate a policy change as this 'had happened only once during the [last] six years': George Roberts, Asylum Seekers Drown as Boat Capsizes off Java; Customs Ship to Offload Separate Rescued Group (27 September 2013) ABC News (online) <http://www.abc.net.au/news/2013-09-27/asylum-seekers-drown-as-boatcapsizes-off-java/4986422>. Later, official sources said that this was a one-off occurrence and that Australia seldom disembarks rescued persons in Indonesia. The Director of the Australian Customs and Border Protection Services said as evidence to a Senate References Committee, '[t]here have been times where under recognised ... SOLAS provisions we have had coordination across the two rescue command and control centres - [Australian Maritime Safety Administration] for our part and the relevant counterpart authority in Indonesia - permission has been granted. There was a case reported in the press where 
rescued asylum-seekers have been held on board larger Australian government ships at sea for extended periods of time. ${ }^{242}$ The method for returning them would have been the same as for intercepted asylum-seekers: towage back to the country from where they departed.

The alleged practice raises a variety of concerns from the perspective of international law. For example, it may be discussed on what legal basis enforcement jurisdiction is exercised against suspected vessels and what measures that may be taken. A central question as regards interdiction in the contiguous zone is whether interception and forcible towage can be considered as an instance of 'control necessary to prevent infringements of its customs, fiscal, immigration and sanitary laws within its territory and territorial sea', which is the control a coastal state is entitled to exercise within its contiguous zone. ${ }^{243}$ Another question is whether Australia has the right to forcibly tow an intercepted vessel in international waters beyond its contiguous zone. At least on the face of it, it is difficult to see how such towage could be consistent with the freedom of navigation. Rather, it seems to impede this freedom. What is of key interest for the present article is the alleged practice of keeping rescued asylum-seekers on board Australian government ships at sea. The central question is which location constitutes a place of safety in such cases. Alternatives include:

1. The first rescue unit (presumably a smaller craft suitable for recovering persons from the water or from foundering vessels);

2. the larger government ship to which the rescued asylum-seekers are transferred from the first rescue unit; or

3. the location at sea where the subsequent towage ends and the towline is released.

Bearing in mind that a place of safety is a place where the survivors' basic human needs (such as food, shelter and medical needs) can be met, ${ }^{244}$ it seems unlikely that a smaller rescue craft can be a place of safety. However, it is not precluded a priori that a vessel at sea can be a place of safety. To the contrary, the IMO Guidelines on the Treatment of Persons Rescued at Sea expressly recognises that a place of safety can be on board a rescue unit or other suitable vessel until the survivors are disembarked to their next destination. A ship at sea that can cater for basic human needs can thus be a

ACV Triton was given permission to land persons who had been rescued, but that is by design': Evidence to Senate References Committee on Breaches of Indonesian Territorial Waters, Parliament of Australia, Canberra, 21 March 2014, 55 (Michael Pezzullo, Director of the Australian Customs and Border Protection Services).

242 See, eg, CPCF v Minister for Immigration and Border Protection (2015) 89 ALJR 207 in which it was revealed that a group of some 160 intercepted asylum-seekers were held on board an Australian customs vessel for nearly a month. See below Part IV(c).

243 UNCLOS art 33(1).

244 IMO Guidelines, IMO Doc MSC 78/26/Add.2 annex 34, annex para 6.12. 
place of safety. Accordingly, it would not be unreasonable to construe the transfer of rescued asylum-seekers to a larger Australian government ship, which can provide for such services, as constituting delivery to a place of safety. This would also allow the rescue operation to be considered terminated once the rescued persons have been transferred to the larger government ship. Any subsequent measures for returning the rescued asylum-seekers could then be considered as a separate operation, beyond the scope of the international disembarkation rules. ${ }^{245}$ Such practice would correspond to the concept of place of safety as set out in the IMO Guidelines on the Treatment of Persons Rescued at Sea.

The alleged practice would also correspond to a more extensive interpretation of the concept of place of safety, as elaborated above, provided that the disembarkation takes into account the particular circumstances of the case (such as the situation on board the assisting ship, on scene conditions, medical needs, and availability of transportation or other rescue units), does not violate applicable human rights (including inter alia the right to family unity), and does not amount to refoulement or prohibited discrimination. The practice must also comply with the temporal element of the disembarkation rules, emphasised both in the SOLAS and SAR Conventions ('disembarkation to be effected as soon as reasonably practicable') and in the IMO Guidelines on the Treatment of Persons Rescued at Sea ('within a reasonable time'). ${ }^{246}$ Thus, a location that can only be reached after unreasonably long time cannot be a place of safety. At first sight, it seems that this temporal aspect effectively prevents rescued persons from being kept on board ships at sea for extended periods of time. However, given that a place of safety can be aboard a rescue unit or other facility at sea, there is nothing in the international disembarkation rules that prevents rescued persons from being held at sea. The international disembarkation rules simply do not regulate treatment after delivery to the place of safety. This shows that the international disembarkation rules are profoundly flexible and permissive even of seemingly harsh deterrence measures. ${ }^{247}$

245 It may be noted that nothing in the SOLAS Convention, the SAR Convention and the IMO Guidelines preclude that operations such as screening and status assessment of rescued persons take place on board an assisting ship (ie at the place of safety). The guidelines simply ensure that such operations should not delay the delivery to a place of safety. Ibid annex para 6.20 reads: "Any operations and procedures such as screening and status assessment of rescued persons that go beyond rendering assistance to persons in distress should not be allowed to hinder the provision of such assistance or unduly delay disembarkation of survivors from the assisting ship(s)'.

246 SOLAS Convention annex ch V reg 33(1-1) (emphasis added); SAR Convention annex para 3.1.9 (emphasis added). See also IMO Guidelines, IMO Doc MSC 78/26/Add.2 annex 34, annex para 6.8: 'Governments and the responsible RCC [Rescue Coordination Centre] should make every effort to minimize the time survivors remain aboard the assisting ship'.

247 This does not preclude that other relevant and applicable treaty obligations (eg, under the Refugee Convention, human rights law and international law against transnational 


\section{(c) CPCF v Minister for Immigration and Border Protection 248}

On 29 June 2014 an Indian-flagged ship was intercepted by Australian authorities about 16 nautical miles from Christmas Island within the contiguous zone of Australia. The ship was carrying some 160 migrants of Sri Lankan nationality and Tamil ethnicity, none of whom had a legal right to enter Australia. Because of a fire in the engine house, the Indian ship had become unseaworthy and its passengers were transferred to an Australian border protection ship. At the direction of the Government of Australia, reflecting a decision of the National Security Committee of Cabinet made on 1 July, the Australian government ship began sailing towards India in order to disembark the detained migrants there. At this time, there was no agreement between Australia and India that permitted the detained migrants to be disembarked in India. After reaching the vicinity of India on about 10 July, the migrants remained detained on board the ship until about 22 July when it was decided that it was not practical to disembark them in India within a reasonable time. The ship then headed to the Australian territory of Cocos (Keeling) Islands where it arrived on about 27 July. The migrants were then disembarked and taken into immigration detention.

One of the detained migrants brought proceedings against the Government of Australia, asserting that the detention on board the border protection ship had been unlawful and claiming damages for wrongful imprisonment. The proceedings were brought within the original jurisdiction of the High Court of Australia. A special case stated questions of law for determination by the Full Court. The Court held, by majority, that the detention was lawful and that s 72(4) of the MPA authorised a maritime officer to detain the plaintiff in order to take him from the contiguous zone of Australia to a place outside of Australia, being India. Section 72(4) states, in relevant part, that a maritime officer may detain a person on a detained vessel and take the person, or cause the person to be taken, to a place outside of Australia. This maritime power is subject to a broad constraint under s 74 of the MPA, which provides that a maritime officer 'must not place or keep a person in a place, unless the officer is satisfied, on reasonable grounds, that it is safe for the person to be in that place'. Importantly, this constraint was interpreted to cover risks of the kind to which nonrefoulement obligations are directed, that is, persecution. ${ }^{249}$

organised crime) and their customary equivalents may be independently violated by how a rescue and disembarkation operation is conducted.

248 CPCF v Minister for Immigration and Border Protection (2015) 89 ALJR 207.

249 'A place which presents a substantial risk that the person, if taken there, will be exposed to persecution or torture would be unlikely to meet the criterion that "that it is safe for the person to be in that place". The constraint imposed by s 74 embraces risks of the kind to which the non-refoulement obligations under the Refugees Convention and the $[C A T]$ are directed': CPCF v Minister for Immigration and Border Protection (2015) 89 ALJR 207, [12] (French CJ). 
In reaching this conclusion, reference was made both to the duty to provide assistance at sea and to the concept of place of safety in the SAR Convention, citing in particular the reference to the non-refoulement obligation in the IMO Guidelines on the Treatment of Persons Rescued at Sea. ${ }^{250}$ Although the Court, for seemingly valid reasons of dualism, ${ }^{251}$ did not apply the international disembarkation rules themselves - but only the corresponding Australian domestic legislation — it seems that the Court thought that the disembarkation rules and the concept of place of safety under the $S A R$ Convention import the non-refoulement obligation. ${ }^{252}$ Nor did the Court pronounce on the issue of whether the non-refoulement obligation under the Refugee Convention applies extraterritorially (as argued by the plaintiff and the UNHCR, which intervened as amicus curiae) or, if it only applies to receiving states in respect of refugees within their territory (as argued by the defendants). ${ }^{253}$ Importantly for the outcome of the case, the Court found that there were no facts which established that transferring the plaintiff to India would amount to refoulement or place him at risk of removal from India to a place in which he would not be safe. Accordingly, the Court found that the detention of the plaintiff was not unlawful and that he was not entitled to compensation for wrongful imprisonment.

The case provides support for an extensive interpretation of the concept of place of safety that imports risks covered by the principle of non-refoulement. However, only a minority of the Court expressly referred to the international disembarkation rules under the SOLAS and SAR Conventions. ${ }^{254}$ The close connection between, and the nearidentical language of, the relevant provisions in the MPA and the international disembarkation rules are arguments in favour of extending the Court's reasoning to the

250 IMO Guidelines, IMO Doc MSC 78/26/Add.2 annex 34, annex para 6.17 refers to the nonrefoulement obligation: 'The need to avoid disembarkation in territories where the lives and freedoms of those alleging a well- founded fear of persecution would be threatened is a consideration in the case of asylum-seekers and refugees recovered at sea': Ibid [15]-[17].

251 See, eg, CPCF v Minister for Immigration and Border Protection (2015) 89 ALJR 207, [21].

252 'To the extent the guidelines applicable to rescue operations might be taken to import an extra-territorial non-refoulement obligation in respect of the persons rescued, the consequences of that obligation ... is subsumed by the requirements imposed by s 74': Ibid 7-8 [16] (French CJ).

253 CPCF, 'Plaintiff's Submissions', Submission in CPCF v Minister for Immigration and Border Protection, S169/2014, 11 September 2014, 10-11 [51]-[53]; UNHCR, 'Seeking Leave to Intervene as Amicus Curiae', Submission in CPCF v Minister for Immigration and Border Protection, S169/2014, 15 September 2014; Minister for Immigration and Border Protection, 'Submissions of the Defendants', Submission in CPCF v Minister for Immigration and Border Protection, S169/2014, 30 September 2014, 3 [20]. See also CPCF v Minister for Immigration and Border (2015) 89 ALJR 207 [10] (French CJ).

254 CPCF v Minister for Immigration and Border Protection (2015) 89 ALJR 207, 6-7 [15][17] (French CJ), 66 [212]-[213] (Crennan J). 
international disembarkation rules and the concept of place of safety. It is noteworthy that only a minority of the Court included explicit references to the international disembarkation rules, although the transfer of the migrants onto the Australian border protection ship clearly constituted a rescue operation.

Nor did the Court specify when the rescue operation was considered to terminate, and thus when the rescued migrants were delivered to a place of safety within the meaning of the international disembarkation rules. Bearing in mind that the IMO Guidelines on the Treatment of Persons Rescued at Sea states in clear terms that a place of safety may be ashore or on board a rescue unit, this need not have been when the rescued migrants were finally put ashore, but may in fact have been once the migrants had been taken on board the border protection ship. Even so, it seems that the Court assumed that the place of safety referred to in the international disembarkation rules must have been a place ashore, being India. From such view it would have been possible to terminate the rescue operation first after the detained migrants had been finally disembarked at the Cocos (Keeling) Islands.

If the Court had understood the place of safety under the international disembarkation rules as a place on board the border protection ship, the Court could have evaluated any subsequent measures, such as the planned disembarkation in India, without regard to the international disembarkation rules. The transfer of the migrants to the border protection ship would then have constituted delivery to a place of safety, allowing the rescue operation to be considered terminated. Any subsequent measures would then have been beyond the scope of the international disembarkation rules.

However, such reasoning would have put the Court in an uncomfortable position. Without the connection to the international disembarkation rules - which the Court found to import the non-refoulement obligations - the Court would have had to answer if the non-refoulement obligation under the Refugee Convention applies extraterritorially. That would have been a controversial matter indeed. ${ }^{255}$ Hence, it seems that the Court used an extensive interpretation of the concept of place of safety in the international disembarkation rules in order to avoid having to answer the controversial question about extraterritorial effects of the non-refoulement obligation under the Refugee Convention.

Although the Court found that the detention of the plaintiff was lawful, as the discharge of him in India would not have contravened s 74 of the MPA, the case is

255 It may be noted that the Government of Australia, acting as defendant, submitted that 'Australia's obligations under the Refugees Convention were not enlivened in respect of the plaintiff, because they arise only with respect to persons who enter Australia's territory'. Minister for Immigration and Border Protection, 'Submissions of the Defendants', Submission in CPCF v Minister for Immigration and Border Protection, S169/2014, 30 September 2014, 3 [20]. 
important for it shows that the removal of asylum-seekers rescued at sea must not contravene the principle of non-refoulement.

\section{v. Concluding Remarks}

At first sight, the complexities of the international disembarkation rules and the concept of place of safety appear as a typical example of legal problems related to regime interaction and fragmentation of international law. However, from a legal-analytical perspective, the complexities are primarily linked to treaty interpretation. Various rules require consideration in the interpretation and application of the concept of place of safety. The key challenge is to grasp and apply the techniques provided by the rules on interpretation of treaties. The complexities may thus not arise from lack of normative content, but rather from overload of objectives that require consideration in the interpretation. The challenge is to interpret the disembarkation rules in the wider context of international law. 